\title{
Equity Market Fragmentation and Capital Investment Efficiency
}

September 2021

\begin{abstract}
This study examines how equity market fragmentation affects firms' capital investment decisions. Recent empirical research finds that market fragmentation lowers trading costs and thus improves market quality. We examine whether this increase in market quality translates into greater revelatory price efficiency, where stock prices reveal with greater precision information to managers and/or creditors about firms' investment opportunities. Consistent with this notion, our findings reveal that the association between capital investment and investment opportunities is increasing in market fragmentation. Additional findings suggest that (a) market fragmentation increases revelatory price efficiency at least in part by encouraging information acquisition by equity investors and (b) the more efficient stock prices inform both managers and creditors about firms' investment opportunities. Inferences based on difference-in-differences and instrumental variable tests are consistent with those based on our primary findings.
\end{abstract}

JEL codes: G12, G31, O16

Keywords: equity market fragmentation, capital investment 


\section{Introduction}

This study examines how equity market fragmentation affects firms' capital investment decisions. Market fragmentation is the extent to which trades are dispersed across multiple trading venues rather than concentrated in one or a small number of venues. In recent years, as the number of trading venues has increased, trading in U.S. equity securities has become more highly fragmented. ${ }^{1}$ This change has led to concerns about the potential negative effects of market fragmentation on market quality. However, recent empirical research finds that market fragmentation improves market quality, as reflected by, e.g., lower bid-ask spreads. We examine whether this increase in market quality translates into greater revelatory price efficiency, which is the extent to which stock prices reveal information that can be useful in capital investment decisions.

Although the theoretical and empirical literature on market fragmentation has examined the effects of market fragmentation on dimensions of market quality, the literature has not examined the effects of market fragmentation on real investment decisions. By lowering trading costs, market fragmentation may encourage information acquisition and order submission, which increases the amount of new information incorporated into stock prices. More informative stock prices can affect real capital investment for at least two reasons. First, prices reveal with greater precision information to managers about their own firms' investment opportunities. Second, prices reveal information to creditors that reduces information asymmetry between creditors and borrowing firms. This reduction in information asymmetry can alleviate financing constraints that limit the pursuit of profitable investment opportunities. In either case, we predict that market

\footnotetext{
${ }^{1}$ For example, whereas 30 years ago U.S. equity trading occurred primarily on the New York Stock Exchange (NYSE), the NYSE currently accounts for less than 20 percent of the trading volume of U.S. equities (Cboe 2021).
} 
fragmentation leads to an increase in the sensitivity of capital investment to investment opportunities.

To test our prediction, following prior literature, we estimate a regression of capital investment on Tobin's q, a standard measure of investment opportunities, which we augment to include an interaction of this variable with market fragmentation. Findings reveal that, consistent with our prediction, the association between capital investment and investment opportunities is increasing in market fragmentation. The sensitivity of investment to investment opportunities increases by $27.4 \%$ across the interquartile range of market fragmentation.

Next, we explore the mechanisms by which market fragmentation may influence real capital investment: (1) how it increases revelatory price efficiency and (2) who learns from more efficient prices, i.e., managers or creditors. Because market fragmentation reflects increased competition among trading venues, investors may benefit through lower trading costs. If lower trading costs allow investors to realize greater benefits from informed trades, information acquisition and trading activity will increase. We investigate the extent to which market fragmentation spurs information acquisition by investors by regressing the number of EDGAR downloads onto beginning-of-year market fragmentation and a set of control variables. We find that market fragmentation is associated with higher levels of EDGAR download activity, which is consistent with market fragmentation increasing incentives for information acquisition. If market fragmentation increases information acquisition and informed trade, we expect current stock prices will reflect more fully future earnings news. Consistent with this prediction, we find that firms with stocks that exhibit greater market fragmentation have higher future earnings response coefficients, i.e., a higher association between current stock returns and future earnings. 
To investigate the extent to which market fragmentation leads to prices that inform managers, i.e., the managerial channel, or creditors, i.e., the financing channel, we compare the effect of market fragmentation on the sensitivity of investment to investment opportunities for firms with differing levels of financing constraints. Because the association between market fragmentation and the sensitivity of investment to investment opportunities increases in financing constraints, the findings suggest that the effects of market fragmentation work through the financing channel. Additional evidence reveals that market fragmentation is associated with a higher sensitivity of new loans to investment opportunities, especially among loans funded by new lenders that are likely to have less information about borrowers, which is consistent with market fragmentation alleviating financing constraints.

We find evidence that the effects of market fragmentation also work through the managerial channel. In particular, we find that (a) the sensitivity of investment to investment opportunities increases with market fragmentation when financing constraints are low and (b) the effect of market fragmentation on the sensitivity of investment to investment opportunities is lower for firms with executives who are more informed, i.e., whose insider trades are more profitable. The latter finding suggests that market fragmentation facilitates less-informed managers' learning from prices.

One alternative explanation for a higher association between investment and investment opportunities when market fragmentation is high is that market fragmentation reduces noise in the measure of investment opportunities. That is, there is no change in firms' investment but the empirical association between investment and investment opportunities is higher because there is less measurement error in investment opportunities. If this were the sole explanation for the higher association between investment and investment opportunities when market fragmentation is high, 
we would not expect to observe real effects of market fragmentation. To examine this possibility, we test whether market fragmentation is associated with higher levels of future profitability, controlling for other factors. We find that market fragmentation is associated with higher one- and three-year-ahead accounting profitability (i.e., return on assets). We also find that the association between current capital expenditures and one- and three-year-ahead profitability is higher when market fragmentation is higher, which is consistent with market fragmentation resulting in more profitable capital investment decisions.

We use two empirical approaches to address the possibility that factors causing firms to have more fragmented trading also are associated with the responsiveness of investment to investment opportunities. The first approach is a difference-in-differences analysis around the introduction of Regulation National Market System (Reg NMS) in 2007. Reg NMS requires that exchanges share data and that trades are executed at the best-quoted price across exchanges, and its introduction led to an increase in market fragmentation. The second approach uses the number of U.S. trading venues as an instrument for market fragmentation. Inferences based on these tests are consistent with those based on our primary findings.

Taken together, our study's findings provide the first empirical evidence of real effects of market fragmentation on corporate decision making. Whereas prior research on market fragmentation documents short-term effects on bid-ask spreads, trading costs, and the speed with which prices reflect market information, we show that market fragmentation is also associated with greater information gathering by investors, greater incorporation of future earnings into prices, revelation of information to creditors that facilitates lending decisions, and more efficient capital investment decisions. Our results suggest that market fragmentation leads to an improvement in revelatory price efficiency, which informs managers and lenders about a firm's investment 
opportunities. Our research complements recent work on factors associated with revelatory price efficiency (e.g., Chen et al. 2007, Jayaraman and Wu 2019) by documenting a new factor that affects revelatory price efficiency, i.e., equity market fragmentation; by providing empirical evidence of a mechanism through which revelatory price efficiency increases, i.e., increased information acquisition; and by extending the notion of revelatory price efficiency from managers learning from prices to include creditors as well.

\section{Background and Predictions}

\subsection{Market Fragmentation}

\subsubsection{Markets and regulation}

Although most U.S. firms initially list their stocks on either the New York Stock Exchange (NYSE) or the Nasdaq Stock Market, they can also apply to have their stocks traded on a number of other U.S. exchanges. ${ }^{2}$ The number of U.S. stock exchanges has increased over the past two decades, from 8 in 1995 to 13 by the end of 2017. Each exchange has different features and listing requirements. For example, whereas the NYSE has a trading floor, other exchanges are entirely electronic. Some exchanges offer co-location services that allow investors, typically institutional investors, faster trade execution. Other exchanges deliberately introduce "speed bumps" that give market makers a chance to reprice bids and offers before an informed trade is executed. Exchanges compete for trading volume based on liquidity, cost, speed, and these other features.

Investors can choose which exchange to trade in. However, investors usually use "smart order routing" software that analyzes prices, liquidity, and features of various trading venues (e.g., speed, fees, etc.) to detect and execute the best available opportunity based on the conditions given

\footnotetext{
${ }^{2}$ Historically, the NYSE was the only U.S. exchange that did not allow trading of stocks listed on rival U.S. exchanges. The NYSE ended that restriction in April 2018 (Osipovich 2018).
} 
by the investor. Frequently, large orders are split into sub-orders that are executed across the various trading venues.

As a result of the increase in number of stock exchanges and technology to route orders efficiently to the various exchanges, the U.S. equity market increasingly exhibits a large degree of fragmentation, which is the extent to which equity trades are dispersed across multiple exchanges rather than concentrated in one or a small number of exchanges. Whereas into the 1990s most equity trading took place on the floor of the NYSE, today no single exchange holds even a $20 \%$ market share (see Appendix 2 for the distribution of trading volume across U.S. exchanges). Even further fragmentation in exchange volume is expected in the future (Redfearn 2019).

The proliferation of exchanges has been supported by the Securities and Exchange Commission (SEC), which issued two major rulings to increase competition among exchanges and promote the dissemination and sharing of information across exchanges. The first ruling, the Securities Acts Amendments of 1975 (SEC 1975), set up a national market system and a system for nationwide clearing and settlement of securities transactions. As a result, investors were provided with information to compare price quotes across trading venues, leading to a convergence in prices across venues.

More recently, the SEC passed Regulation National Market System (Reg NMS, SEC 2005), which was designed to increase competition in equity markets, thus promoting more efficient trading services and more efficient pricing of stocks (SEC Release No. 34-61358). ${ }^{3}$ A key provision of the regulation, the Access Rule, reinforced the sharing of market data across exchanges that was originally prescribed in the Securities Acts Amendments of 1975. Another key provision, the Order Protection Rule or trade-through rule, required exchanges to guarantee that

\footnotetext{
${ }^{3}$ The Markets in Financial Instruments Directive similarly encouraged competition among European markets by allowing new trading venues to compete with traditional stock exchanges.
} 
trades are executed at prices no worse than those available at other trading venues. Together, the sharing of data and guarantee of order protection encouraged competition across exchanges to attract trades. $^{4}$

There are at least three benefits to investors from increased fragmentation. First, by increasing competition among trading venues, fragmentation could lower average trading costs as exchanges offer favorable terms and lower fees to investors. Second, the proliferation of trading venues could allow venues to specialize, offering different services to investors (e.g., co-location or access to data). Third, by encouraging competition across trading venues, fragmentation could foster trade innovations, such as reductions in latency. On the other hand, fragmentation may increase investors' trading costs. Notably, as trading volume is divided across multiple trading venues, execution risk may increase as investors find it more difficult to find counterparties, particularly when trading in stocks with lower volume. ${ }^{5}$ Whether fragmentation leads to a net cost or benefit to investors is an empirical question. As we discuss in the next section, empirical research documents that market fragmentation reduces trading costs and improves market quality, especially for larger firms.

\subsubsection{Related research}

Theoretical research highlights both disadvantages and advantages to market fragmentation. Mendelson (1987) shows that fragmentation may isolate individuals for whom there are mutually beneficial trades, because they are trading on different venues. Chowdhry and Nanda (1991) posits that fragmentation can increase adverse selection costs. Further, Pagano

\footnotetext{
${ }^{4}$ For more detail, see https://www.sec.gov/rules/final/34-51808.pdf.

${ }^{5} \mathrm{O}$ 'Hara and Ye (2011) explains that market fragmentation could also harm market quality by reducing the liquidity available not only in individual markets but also in aggregate. This could occur if market fragmentation reduces the enforcement of time priority across markets, thereby disincentivizing traders from posting limit orders, or if access to trading venues is limited for some traders.
} 
(1989) predicts that stocks trading in less liquid markets may be adversely affected by fragmentation. As the set of potential counterparties is spread across more trading venues, it becomes more difficult for individual traders to find a counterparty in any particular venue.

On the positive side, Stoll (2001) suggests that the ability to direct trades to specific trading venues can foster price efficiency, as different exchanges offer unique features to satisfy traders' needs (Harris and Raviv 1993). Malamud and Rostek (2017) shows that when traders' risk preferences are sufficiently heterogeneous, fragmented markets produce outcomes that are welfare superior to a centralized market. Chen and Duffie (2021) shows that fragmentation leads to more aggressive order submission (across all exchanges) and better rebalancing of unwanted positions across traders, which leads to prices that better reflect traders' private information. This occurs because traders can split orders across exchanges to limit their price impact on a given exchange.

Empirical studies examine the effects of market fragmentation on various dimensions of market quality, including bid-ask spreads, trading costs, and the speed with which prices reflect market information. O'Hara and Ye (2011) finds that U.S. stocks with more fragmented trading have lower bid-ask spreads, faster execution of trades, and price movements that are closer to a random walk. The benefits of market fragmentation have also been documented for European equity markets (Foucault and Menkveld 2008, Degryse et al. 2015, Félez-Veñas 2017, Gresse 2017), Australian equity markets (Aitken et al. 2017), and U.S. option markets (De Fontnouvelle et al. 2003). An exception is Chung and Chuwonganant (2012), which finds that order execution speed is slower, order fill rate is lower, and order cancellation rate is higher for most trades after Reg NMS, which resulted in increased market fragmentation.

A few studies document that the effects of market fragmentation vary with the size of firms (O’Hara and Ye 2011, Degryse et al. 2015, Gresse 2017, Haslag and Ringgenberg 2017). For 
example, Haslag and Ringgenberg (2017) shows that the effects of fragmentation differ depending on market capitalization. Specifically, although the study finds an on-average negative association between fragmentation and bid-ask spreads (a one standard deviation increase in fragmentation is associated with a $2.2 \%$ reduction in bid-ask spreads), the association is significantly more negative for large firms but positive for small firms. Similarly, the association between fragmentation and the speed of price adjustment to new information is positive for large firms but negative for small firms. Haslag and Ringgenberg (2017) concludes that the negative effects of Reg NMS documented by Chung and Chuwonganant (2012) are concentrated in small firms.

\subsection{Hypothesis Development}

Academic research documents that managers incorporate investors' private information obtained from stock prices when making corporate investment decisions (e.g., Hayek 1945, Gebhardt et al. 2005, Chen et al. 2007, Downing et al. 2009, Bakke and Whited 2010, Jayaraman and $\mathrm{Wu}$ 2019, Ye et al. 2019). As explained in Chen et al. (2007), if at a given point in time managers decide on the level of investment attempting to maximize the expected value of the firm, they will use all information available to them at that point. This includes both the information in the stock price and other information that managers have and that has not yet been incorporated into the stock price. In this case, investment will be more sensitive to stock price when the price provides more information that is new to managers. Bond et al. (2012) characterizes the extent to which stock prices reveal information that can be useful in investment decisions as "revelatory price efficiency" (RPE). As RPE increases, the sensitivity capital investment to marginal q increases.

Prior research provides evidence that equity market fragmentation improves market quality, particularly for larger firms (e.g., O’Hara and Ye 2011, Haslag and Ringgenberg 2017). If 
improvements in market quality, e.g., lower trading costs, lead to greater opportunities for traders to benefit from informed trade, we expect more information gathering and ultimately more private information in prices. As a result, if market fragmentation leads to prices with greater RPE, i.e., prices that reveal with greater precision information to managers about their firms' investment opportunities, we expect a higher association between capital investment and Tobin's q when market fragmentation is higher. We refer to this mechanism as the managerial channel.

In addition, if stock prices have greater RPE, then the firm can benefit when making investment decisions because prices are more informative also to the firm's external capital providers. ${ }^{6}$ When there is information asymmetry between a firm and its capital providers, the firm cannot convey credibly the value of its investment opportunities to them. As noted by prior research (e.g., Myers and Majluf 1984), this leads to financing constraints that limit otherwise profitable investments. In this setting of financing constraints, capital investment exhibits a lower association with marginal q because not all investment opportunities can receive the necessary financing.

However, firms can mitigate financing constraints by providing credible information to creditors. For example, Biddle and Hilary (2006) finds that better accounting information reduces information asymmetry between managers and outside suppliers of capital. Similarly, Biddle et al. (2009) finds that firms with better accounting quality are less likely exhibit under-investment arising from financing constraints.

\footnotetext{
${ }^{6}$ We consider debt financing but not equity financing for two reasons. First, we are interested in the transfer of information across, rather than within groups, i.e., from stock prices, which are set by equity investors, to managers and creditors. Second, publicly traded firms typically obtain more debt than equity financing, and do so more regularly. To the extent market fragmentation reduces the cost of equity, we would expect a substitution from debt to equity financing, which would bias against our finding evidence of prices informing creditors.
} 
Financing constraints also can be mitigated if there are sources of information from outside the firm that reduce information asymmetry between managers and creditors. One important source of information for creditors is the borrowing firm's stock price. A stock price with higher RPE can better inform not only managers but also creditors about investment opportunities. Creditors' ability to learn from stock prices can reduce information asymmetry and thus alleviate financing constraints (Fleming et al. 1998, Norden and Weber 2004, Gebhardt et al. 2005, Downing et al. 2009).

If market fragmentation leads to prices that reveal information to creditors that reduces information asymmetry between the creditors and borrowing firms, thereby alleviating financing constraints that limit capital investment (Myers and Majluf 1984, Fazzari et al. 1988, Bond et al. 2004), we expect a higher association between capital investment and Tobin's q when market fragmentation is higher. We refer to this mechanism as the financing channel.

Regardless of whether the effects of market fragmentation work through the managerial channel or the financing channel, we hypothesize that an increase in market fragmentation leads to an increase in the sensitivity of capital investment to investment opportunities.

\section{Sample and Data}

To construct the variables we use in our analyses, we obtain exchange location and trade data from the TAQ database, stock price and return data from CRSP, accounting data from Compustat, institutional ownership and insider trading data from Thomson Reuters, analyst coverage data from I/B/E/S, loan data from DealScan, and data on EDGAR downloads from the Securities and Exchange Commission. We include only ordinary common shares in U.S. firms (share codes 10 and in 11 in CRSP). We exclude observations with share prices below $\$ 1.00$ and observations with missing values for the variables required in the regression analyses. We 
winsorize each continuous variable at the $1^{\text {st }}$ and $99^{\text {th }}$ percentiles. Our primary sample comprises 109,020 firm-year observations, with smaller subsamples based on data availability for some of our additional analyses.

Table 1, Panel A, lists the 14 trading venues in existence at the end of our sample period, 2017. The 14 trading venues include 13 exchanges and an aggregation of trades from various nonexchange trading venues (e.g., dark pools), which we obtain from FINRA. ${ }^{7}$ Panel B lists, by year, the number of trading venues and sample mean of market fragmentation across those venues. The panel reveals two trends. First, the number of trading venues increases from 9 in 1995 to 15 in 2010 before levelling out at 14 by the end of the sample period. Second, fragmentation in trading across venues is generally increases throughout the sample period, rising from 0.08 in 1995 to 0.72 by 2017 . The largest single-year increase occurs in 2008 , the year following the implementation of Reg NMS, which was intended to increase competition among trading venues.

Table 2, Panels A and B, presents sample summary statistics and correlations among variables. Panel A reveals that the average firm invests 5.69\% of total assets per year, has a Tobin's $\mathrm{q}$ of 2.21 , and cash flows equal to $3.33 \%$ of total assets. Panel B reveals that market fragmentation, $F R A G$, and the number of trading venues, \#VENUES, are positively correlated (0.85), as expected. Further, market fragmentation is associated with lower levels of capital investment and lower values of Tobin's q; however, pairwise correlations cannot speak to the association between market fragmentation and the sensitivity of investment to Tobin's q, which is the focus of our regression analyses that follow.

\footnotetext{
${ }^{7}$ We calculate market fragmentation across the 14 trading venues, following prior research (e.g., Haslag and Ringgenberg 2017). Inferences are unchanged when we calculate market fragmentation across only the 13 exchanges, or when controlling for the extent of off-exchange trading. The former result is not surprising given the high correlation between the two measures of market fragmentation (0.93).
} 
To gain insight into the firm characteristics associated with market fragmentation, we estimate a descriptive regression of market fragmentation onto a set of firm-level characteristics. In particular, we estimate the following regression:

$$
\begin{aligned}
& F R A G_{t}=b_{0}+b_{1} S I Z E_{t}+b_{2} M B_{t}+b_{3} R O A_{t}+b_{4} L E V E R A G E_{t}+b_{5} I D I O V O L_{t} \\
& +b_{6} \text { TURNOVER }_{t}+b_{7} \text { ANALYST }_{t}+b_{8} \text { INSTOWN }_{t}+b_{9} \text { NYSE }_{t} \\
& + \text { b10 NASDAQ } Q_{t}+\text { Industry Fixed Effects }+ \text { Year Fixed Effects }+e_{t} \text {, }
\end{aligned}
$$

where FRAG equals one minus the Herfindahl-Hirschman Index measure of the concentration of trading across trading venues during the fiscal year. Specifically, for each stock and fiscal year, we use the TAQ database to calculate $F R A G$ as $1-\Sigma s_{j}^{2}$, where $s_{j}$ is the proportion of trades that occur on trading venue $j$.

SIZE is the natural log of total assets; $M B$ is the ratio of market value of equity to book value of equity; ROA is net income before extraordinary items divided by total assets; LEVERAGE is the book value of total debt divided by sum of the book value of total debt and market value of equity; IDIOVOL is the standard deviation of idiosyncratic daily stock returns over the fiscal year, calculated from the Carhart (1997) four-factor model; TURNOVER is the natural log of trading volume during the fiscal year scaled by number of shares outstanding; ANALYST is the natural log of one plus the number of analysts who issue an earnings forecast during the fiscal year; and INSTOWN is the percentage of common shares outstanding held by institutional investors. We include indicator variables for the primary listing exchange of the firm's stock: the NYSE (NYSE), Nasdaq (NASDAQ), or any other exchange (indictor omitted). Appendix 1 provides definitions for all variables used in this study.

Column (1) of Table 2, Panel C, presents the results from the regression of FRAG onto firm characteristics with industry and year fixed effects. Firms that exhibit a greater degree of market fragmentation tend to be larger $(S I Z E$ coef. $=0.007, t$-stat $=12.44)$, less profitable $(R O A$ coef. $=-$ 
$0.019, t$-stat $=-7.56)$, and less volatile $($ IDIOVOL coef. $=-0.006, t$-stat $=-15.84)$. Firms with greater market fragmentation are more actively traded $(T U R N O V E R$ coef. $=0.039, t$-stat $=21.99)$, are more actively followed by analysts $(A N A L Y S T$ coef. $=0.016, t$-stat $=19.14)$, and tend to be owned by institutional investors (INSTOWN coef. $=0.026, t$-stat $=9.80)$. Finally, firms with a primary listing on the NYSE (NYSE coef. $=-0.035, t$-stat $=-8.87)$ or NASDAQ $(N A S D A Q$ coef. $=-0.097$, $t$-stat $=-26.48)$ exhibit less market fragmentation than other firms.

Column (2) presents the results from the regression of FRAG onto firm characteristics with firm rather than industry fixed effects. When focusing on within-firm rather than across-firm variation, the results are qualitatively similar with the following exceptions. Market fragmentation is higher in years when firms have a lower book-to-market ratio $(M B$ coef. $=-0.034, t$-stat $=-3.39)$ and are more highly levered $($ LEVERAGE coef. $=0.030, t$-stat $=7.06)$.

\section{Market Fragmentation and the Sensitivity of Investment to Investment Opportunities}

To investigate the effect of fragmentation on capital investment, we adapt the investment model in Chen et al. (2007), which allows the sensitivity of investment to investment opportunities to vary with the informativeness of stock price. In particular, we estimate the following regression model, which permits the sensitivity of investment to investment opportunities to vary with the degree of market fragmentation:

$$
\begin{aligned}
C A P X_{t} & =b_{0}+b_{1} Q_{t-1}+b_{2} Q_{t-1} \times F_{R A G}+1+b_{3} F_{t A G} G_{t-1}+b_{4} C F_{t}+b_{5} \text { RETURN3 }_{t} \\
& +b_{6} I N V A S S E T S_{t-1}+\text { Firm Fixed Effects }+ \text { Year Fixed Effects }+e_{t},
\end{aligned}
$$

where $C A P X$ is annual capital expenditures scaled by beginning-of-year total assets ${ }^{8} ; Q$ is the sum of the market value of equity and book value of debt, divided by the beginning-of-year book value

\footnotetext{
${ }^{8}$ We estimate variations of Eq. (2a) using two alternative measures of investment - the sum of capital expenditures and research and development expenditures, and the change in total assets. Untabulated analyses reveal that our primary inferences are unchanged when using these measures.
} 
of total assets; and $C F$ is net operating cash flow, scaled by beginning-of-year total assets. ${ }^{9}$ Following Chen et al. (2007), we include as a control the value-weighted, market-adjusted stock return over the current and subsequent two years, RETURN3, because prior research suggests firms tend to invest when their stocks are overvalued (Loughran and Ritter 1995, Baker and Wurgler 2002). Also, we include the inverse of total assets at the beginning of the year, INVASSETS, as a control for the spurious correlation between capital expenditures and Tobin's q that may arise from scaling capital expenditures by total assets (Chen et al. 2007). We include firm and year fixed effects as controls for unobserved heterogeneity across firms and over time, and we cluster standard errors by firm.

We predict $b_{2}$ is positive if market fragmentation is associated with an increase in revelatory price efficiency that informs either managers or creditors about the firm's investment opportunities.

Table 3 presents findings from estimations of Equations (2a) and (2b) in Columns (2) and (3), respectively. Column (1) presents findings from a base model that excludes market fragmentation. Consistent with prior research, the base model estimation indicates that capital investment is significantly positively associated with investment opportunities $(Q$ coef. $=0.588, t$ stat $=24.41)$ and internal cash flows $(C F$ coef. $=0.033, t$-stat $=10.12) .{ }^{10}$

Consistent with our prediction, the findings in Column (2) reveal that the association between capital investment and investment opportunities is increasing in market fragmentation. In particular, the coefficient on the interaction between $Q$ and $F R A G$ is significantly positive (coef. $=0.248, t$-stat $=3.45)$. In terms of economic significance, the sensitivity of investment to

\footnotetext{
${ }^{9}$ For ease of exposition, we use the same notation for coefficients across equations. In all likelihood they differ.

${ }^{10}$ Throughout the study, we use a 0.05 significance level under a one-sided alternative when we have a signed prediction and under a two-sided alternative otherwise.
} 
investment opportunities increases from $0.555(=0.548+0.03 \times 0.248)$ at the first quartile of FRAG to $0.707(=0.548+0.64 \times 0.248)$ at the third quartile of $F R A G$, which is an increase of $27.4 \% .^{11,12}$

Because prior research (i.e., O'Hara and Ye 2011, Degryse et al. 2015, Gresse 2017, Haslag and Ringgenberg 2017) finds that improvements in market quality resulting from increased market fragmentation are concentrated primarily in large firms, we estimate a version of Equation (2a) that allows the effect of market fragmentation to vary with firm size.

$$
\begin{aligned}
& C A P X_{t}=b_{0}+b_{1} Q_{t-1}+b_{2} Q_{t-1} \times F R A G_{t-1}+b_{3} Q_{t-1} \times F R A G_{t-1} \times R K S I Z E_{t-1} \\
& +b_{4} Q_{t-1} \times R K S I Z E_{t-1}+b_{5} F R A G_{t-1} \times R K S I Z E_{t-1}+b_{6} F_{R A G_{t-1}}+b_{7} R_{K S I Z E_{t-1}} \\
& +b_{8} C F_{t}+b_{9} \text { RETURN }_{t}+b_{10} \text { INVASSETS } t-1+\text { Firm Fixed Effects } \\
& + \text { Year Fixed Effects }+e_{t} \text {, }
\end{aligned}
$$

We measure firm size, RKSIZE, as the decile rank of the firm's total assets, scaled between 0 and 1 . We predict $b_{3}$ is positive if the effects of market fragmentation increase with firm size.

The findings in Table 3, Column (3), reveal that the effects of market fragmentation on the sensitivity of investment to investment opportunities and to cash flows increase with firm size. In particular, the coefficient on the three-way interaction among $Q, F R A G$, and RKSIZE is significantly positive (coef. $=0.871, t$-stat $=3.34$ ). This finding is consistent with that of Haslag and Ringgenberg (2017), which finds that improvements in market quality resulting from increased market fragmentation are concentrated primarily in large firms.

\footnotetext{
${ }^{11}$ To test whether the association between market fragmentation and the sensitivity of investment to investment opportunities is evident in the cross section, and not simply a result of increasing market fragmentation over time, we estimate year-by-year regressions of Eq. (2a). Consistent with our primary findings, the coefficient on the interaction between $Q$ and FRAG is significantly positive (mean coef. $=0.442$, Fama-MacBeth $(1973) t$-stat $=2.68$ ).

${ }^{12}$ Because the associations we observe in Table 3 could result from correlated omitted variables, we estimate an additional equation that includes controls for several firm characteristics that may affect both market fragmentation and the sensitivity of investment to investment opportunities. We augment Equation (2a) with the variables from Equation (1), both as main effects and interactions with the $Q_{t-1} \times F R A G_{t}$ term. Consistent with the results in Table 3, Panel A, these untabulated findings reveal that the sensitivity of investment to investment opportunities increases with market fragmentation in the presence of linear $(t$-stat $=2.20)$ or both linear and interactive controls $(t$-stat $=2.28)$.
} 


\section{How Market Fragmentation Improves Revelatory Price Efficiency}

Next, we examine one potential mechanism by which market fragmentation leads to prices with greater revelatory efficiency. Prior research suggests that market fragmentation results in lower trading costs. The decrease in trading costs may result in an increase in information acquisition and thus more informed trading and informative prices.

To test this possibility, we examine the association between market fragmentation information acquisition by tracking downloads of regulatory filings from the SEC's EDGAR database, because investors and other market participants access firms' regulatory filings to inform investment decisions (Drake et al. 2015, Lee et al. 2015, Loughran and McDonald 2017, Crane et al. 2018, Chen et al. 2019, Gibbons et al. 2019). To test whether information acquisition increases with market fragmentation, we estimate the following regression model:

$$
\begin{aligned}
& E D G A R 10 K Q_{t} \text { or } E D G A R_{t}=b_{0}+b_{1} F R A G_{t-1}+b_{2} S I Z E_{t}+b_{3} M B_{t}+b_{4} R O A_{t} \\
& +b_{5} \text { LEVERAGE }_{t}+b_{6} \text { IDIOVOL }_{t}+b_{7} \text { TURNOVER }_{t}+b_{8} \text { ANALYST }_{t} \\
& +b_{9} I_{N S T O W N}+\text { Firm Fixed Effects }+ \text { Year Fixed Effects }+e_{t} \text {, }
\end{aligned}
$$

where $E D G A R 10 K Q_{t}\left(E D G A R_{t}\right)$ is the natural log of the number of a firm's $10-\mathrm{K}$ or $10-\mathrm{Q}$ filings (for any filing) downloaded from EDGAR during the fiscal year.

Table 4, Panel A, reveals that when market fragmentation is higher, the firm's SEC filings are more frequently downloaded. This is true for $10-\mathrm{K}$ and $10-\mathrm{Q}$ filings $\left(F R A G_{t}\right.$ coef. $=0.114, t$ stat $=2.69)$ and for all SEC filings $\left(F R A G_{t}\right.$ coef. $=0.150, t$-stat $\left.=5.93\right)$.

To the extent information acquisition and informed trading increases with market fragmentation, we expect that stock prices will more fully reflect information in future earnings. To test this conjecture, we augment a future-earnings-response-coefficient model (Lundholm and Myers 2002, Ettredge et al. 2005) with market fragmentation and its interactions with current and future earnings:

$R E T U R N_{t}=b_{0}+b_{1} \Delta E A R N_{t}+b_{2} \Delta E A R N_{t+1}+b_{3} \Delta E A R N_{t} \times F R A G_{t-1}+b_{4} \Delta E A R N_{t+1} \times F R A G_{t-1}$ 


$$
+b_{5} \text { FRAG }_{t-1}+b_{6} \text { RETURN }_{t+1}+b_{7} \text { RETURN }_{t-1}+b_{8} \operatorname{SIZE}_{t-1}+b_{9} M_{t-1}
$$

+ Firm Fixed Effects + Year Fixed Effects $+e_{t}$,

where RETURN is the firm's annual buy-and-hold stock return over the fiscal year and $\triangle E A R N$ is the change in income before extraordinary items, scaled by market value of equity at the beginning of the year. If market fragmentation leads to stock prices that more quickly incorporate future earnings information, we predict $b_{4}$ is positive. We include as controls proxies for risk factors identified in prior research. These include the prior-year stock return, firm size (SIZE), and the ratio of market value of equity to book value of equity $(M B)$. We estimate Equation (4) with firm and year fixed effects.

Table 4, Panel B, presents findings from the estimation of Equation (4). When fragmentation equals zero, the contemporaneous earnings response coefficient is positive, which is consistent with prior research $\left(\triangle E A R N_{t}\right.$ coef. $=0.383, t$-stat $\left.=4.29\right)$. This coefficient does not vary significantly with the degree of market fragmentation, i.e., the $\triangle E A R N_{t} \times F R A G$ coefficient, 0.035 , is insignificant $(t$-stat $=0.25)$. However, the future earnings response coefficient increases as market fragmentation increases, i.e., the $\triangle E A R N_{t+1} \times F R A G$ coefficient, 0.228 , is significantly positive $(t$-stat $=3.05)$, which is consistent with the notion that market fragmentation leads to stock prices that more quickly incorporate future earnings information.

\section{Does Fragmentation Work through the Managerial Channel, Financing Channel, or Both?}

As described in Section 2.2, there are two channels through which market fragmentation can increase the sensitivity of capital investment to Tobin's q. Market fragmentation can lead to prices that reveal with greater precision information either to managers (the managerial channel) or to creditors (the financing channel) about the firm's investment opportunities. To determine the extent to which one or both of the channels contributes to the increase in sensitivity of capital investment to investment opportunities, we estimate the following regression model: 


$$
\begin{aligned}
& C A P X_{t}=b_{0}+b_{1} Q_{t-1}+b_{2} Q_{t-1} \times F R A G_{t-1}+b_{3} Q_{t-1} \times F R A G_{t-1} \times R_{K C O N S T R} \text { CON }_{t-1} \\
& +b_{4} Q_{t-1} \times R \text { KCONSTR }_{t-1}+b_{5} \text { FRAG }_{t-1} \times R \text { KCONSTR }_{t-1}+b_{6} \text { FRAG }_{t-1} \\
& +b_{7} \text { RKCONSTR }_{t-1}+b_{8} \text { RETURN }_{t}+b_{9} \text { INVASSETS }_{t-1}+\text { Firm Fixed Effects } \\
& + \text { Year Fixed Effects }+e_{t} \text {, }
\end{aligned}
$$

where RKCONSTR is the decile rank of the Delay Investment Score as measured by Hoberg and Maksimovic (2015), scaled between 0 and 1. If the effects of market fragmentation work only through the managerial channel (financing channel), then we predict $b_{2}\left(b_{3}\right)$ is positive and $b_{3}\left(b_{2}\right)$ is zero. If the effects of market fragmentation work at least partially through both channels, we predict both $b_{2}$ and $b_{3}$ are positive.

The findings presented in Table 5, Panel A, reveal that the effects of market fragmentation on the sensitivity of investment to investment opportunities are larger for firms that are more financially constrained. In particular, the coefficient on the three-way interaction among $Q, F R A G$, and RKCONSTR is significantly positive (coef. $=0.332, t$-stat $=1.92)$. This finding suggests that the effects of market fragmentation work through the financing channel, where market fragmentation benefits financially constrained firms that are more likely to rely on external financing. The positive coefficient on the interaction between $Q$ and FRAG (i.e., when financing constraints are in the lowest decile) provides evidence that the effects of market fragmentation also work through the managerial channel $($ coef. $=0.202, t$-stat $=1.84) .{ }^{13}$

Another approach to provide evidence on the financing channel uses a firm's accounting quality. Biddle et al. (2009) finds that firms with better accounting quality are less likely exhibit under-investment arising from financing constraints. To the extent that accounting quality and market fragmentation are substitutes in reducing information asymmetry between firms and

\footnotetext{
${ }^{13}$ Inferences are unchanged when we estimate Eq. (5) using an alternative measure of financing constraints based on the Kaplan and Zingales (1997) index of financial constraints, updated following Hadlock and Pierce (2010). Untabulated findings reveal that the coefficient on the three-way interaction among $Q, F R A G$, and RKCONSTR is $0.574(t$-stat $=2.86)$.
} 
creditors, i.e., the financing channel, the positive effect of market fragmentation on the sensitivity of capital investment to investment opportunities will be lower when accounting quality is higher.

To test our predictions, we estimate the following regression model:

$$
\begin{aligned}
C A P X_{t} & =b_{0}+b_{1} Q_{t-1}+b_{2} Q_{t-1} \times F R A G_{t-1}+b_{3} Q_{t-1} \times F R A G_{t-1} \times R K A Q_{t-1} \\
& +b_{4} Q_{t-1} \times R K A Q_{t-1}+b_{5} F R A G_{t-1} \times R K A Q_{t-1}+b_{6} F R A G_{t-1}+b_{7} R K A Q_{t-1}+b_{8} C F_{t} \\
& +b_{9} R E T U R N 3_{t}+b_{10} I_{N V A S S E T S}+\text { Firm Fixed Effects }+ \text { Year Fixed Effects }+e_{t}
\end{aligned}
$$

where $R K A Q$ is the decile rank of the Dechow and Dichev (2002) earnings quality measure, calculated following Francis et al. (2005) and scaled between 0 and 1. If the effects of market fragmentation work through the financing channel, we predict $b_{3}$ is negative. If the effects of market fragmentation work through the managerial channel, we predict $b_{3}$ equals zero.

The findings in Table 5, Panel B, reveal that the effects of market fragmentation on the sensitivity of investment to investment opportunities decreases with accounting quality. In particular, the coefficient on the three-way interaction among $Q, F R A G$, and $R K A Q$ is significantly negative (coef. $=-1.280, t$-stat $=-5.12$ ). As with the findings in Panel A, the findings in Panel B are consistent with market fragmentation working through the financing channel, where improved revelatory price efficiency resulting from market fragmentation and the quality of accounting information act as substitute sources of information to creditors. ${ }^{14}$

To provide additional evidence on the financing channel, we next analyze the relation between market fragmentation and the amount and characteristics of new loans. The demand for borrowing increases with the value of investment opportunities a firm faces. If market fragmentation eases financing constraints, we expect that the association between new borrowings and investment opportunities increases in the degree of market fragmentation. When financing

\footnotetext{
${ }^{14}$ Although this finding is consistent with market fragmentation working through the financing channel, it cannot rule out the managerial channel because improved financial disclosures may also facilitate managers' learning from stock prices (Jayaraman and Wu 2019).
} 
constraints are lower, firms are more freely able to borrow as needed to fund new investments. Further, we expect this effect of market fragmentation to be larger for loans obtained from creditors without a prior lending relationship with the firm. Because creditors gather proprietary, borrowerspecific information from interactions with borrowers over time, creditors increase credit availability to borrowers with whom they have existing relationships (e.g., Petersen and Rajan 1994, Berger and Udell 1995). We expect the information learned from more informative stock prices is more relevant to creditors without prior relationships that lack proprietary information about the borrower.

To test these predictions, we estimate the following regression model:

$$
\begin{aligned}
& \text { NEWLOANS } S_{t}=b_{0}+b_{1} Q_{t-1}+b_{2} Q_{t-1} \times F R A G_{t-1}+b_{3} Q_{t-1} \times F R A G_{t-1} \times N O N R E L_{t-1} \\
& \quad+b_{4} Q_{t-1} \times N O N R E L_{t-1}+b_{5} F R A G_{t-1} \times N O N R E L_{t-1}+b_{6} N O N R E L_{t-1}+b_{7} \text { FRAG }_{t-1} \\
& \quad+b_{8} \text { LEVERAGE }_{t-1}+b_{9} \text { SIZE }_{t-1}+b_{10} \text { ROA }_{t-1}+b_{11} \text { IDIOVOL }_{t-1}+b_{12} I_{N S T O W N} N_{t-1} \\
& \quad+b_{13} \text { ANALYST }_{t-1}+\text { Firm Fixed Effects }+ \text { Year Fixed Effects }+e_{t}
\end{aligned}
$$

where NEWLOANS is the natural log of the total dollar amount of new loans during the fiscal year. As defined previously, $Q$ represents investment opportunities at the beginning of the fiscal year, and FRAG is the degree of market fragmentation at the beginning of the fiscal year. NONREL equals 1 if the ratio of non-relationship loans to total loans during the year is above the sample median, 0 otherwise. Following Bharath et al. (2009), we identify a loan as relationship-based if the firm borrowed from the same creditor at least once during the previous five years.

If market fragmentation reduces financing constraints, then $b_{2}$ is positive. Further, if the increase in revelatory price efficiency resulting from increased market fragmentation benefits creditors without prior lending relationships more so than creditors with prior lending relationships, then $b_{3}$ is positive.

We include controls for leverage, LEVERAGE, because firms with greater amounts of debt outstanding are not as freely able to borrow. All else equal, we expect that information asymmetry 
is lower between creditors and large, profitable borrowers with lower levels of equity volatility and higher levels of institutional ownership and analyst following, which results in greater access to credit for such borrowers. We measure firm size as the natural log of total assets, (SIZE), and profitability as the return on assets, ROA. IDIOVOL is idiosyncratic volatility, INSTOWN is the percentage of the firm's shares that are held by institutions, and ANALYST is the natural log of one plus the number of analysts following the firm.

Table 5, Panel C, presents the results from the estimation of Equation (7). Column (1) presents the results from the estimation of an abbreviated version of Equation (7) that does not distinguish relationship-based loans from non-relationship-based loans, and Column (2) presents the results from the estimation of the full model in Equation (7).

The significantly positive coefficient on the interaction between $Q$ and $F R A G$ in Column (1) reveals that market fragmentation is associated with a higher sensitivity of new loans to investment opportunities on average (coef. $=0.075, t$-stat $=4.05$ ), which is consistent with market fragmentation alleviating financing constraints. Further, the significantly positive coefficient on the three-way interaction among $Q, F R A G$, and NONREL (coef. $=0.134, t$-stat $=2.22$ ) in Column (2) indicate the effect of market fragmentation arises primarily from a reduction of information asymmetry between creditors and borrowers without a prior lending relationship.

Taken together, the results presented in Table 5 suggest that the effects of market fragmentation work through the financing channel, where a firm's stock price decreases information asymmetry between the firm and creditors by revealing information to creditors, which alleviates financing constraints.

The results presented in Table 5, Panel A, suggest that the effects of market fragmentation also work through the managerial channel. We explore this possibility further by examining the 
profitability of insider trades made by the firm's executives. We expect that managers are less likely to learn from stock prices when they already possess more private information about their firms. We measure managers' private information using the profitability of their insider trading, because insider trades reveal private, firm-specific information not impounded in price (Seyhun 1992, Seyhun 1998, Meulbroek 1992, Damodoran and Liu 1993, Ke et al. 2002, Piotroski and Roulstone 2005, Chen et al. 2007). We estimate the following regression model:

$$
\begin{aligned}
C A P X_{t} & =b_{0}+b_{1} Q_{t-1}+b_{2} Q_{t-1} \times F_{R A G}+1+b_{3} Q_{t-1} \times F_{R A G} \times G_{t-1} \times \text { IINSTRADE }_{t-1} \\
& +b_{4} Q_{t-1} \times \text { RKINSTRADE } E_{t-1}+b_{5} \text { FRAG }_{t-1} \times \text { RKINSTRADE }_{t-1}+b_{6} \text { FRAG }_{t-1} \\
& +b_{7} \text { RKINSTRADE }_{t-1}+b_{8} \text { CF }_{t}+b_{9} \text { RETURN } 3_{t}+b_{10} \text { INVASSETS }_{t-1} \\
& + \text { Firm Fixed Effects }+ \text { Year Fixed Effects }+e_{t},
\end{aligned}
$$

where RKINSTRADE is the decile rank of insider trading profitability and scaled between 0 and 1. Following Jagolinzer et al. (2011) and Foucault and Fresard (2014), we measure the profitability of insiders' trades each day as the intercept (or alpha) from the four-factor Carhart (1997) model estimated over the 30 days following each transaction. We multiply the alpha by -1 for sales and calculate the average trading profits for each firm each year. If the effects of market fragmentation work through the managerial channel, then we predict $b_{3}$ is negative.

The findings in Table 6 reveal that the effects of market fragmentation on the sensitivity of investment to investment opportunities decreases with the profitability of trading by the firm's insiders, which suggests the effects of market fragmentation may also work through the managerial channel. The coefficient on the three-way interaction among $Q, F R A G$, and RKINSTRADE is significantly negative (coef. $=-0.363, t$-stat $=-2.59)$.

\section{Analyses Addressing Alternative Explanations}

\subsection{Analysis of Real Effects of Market Fragmentation}

One alternative explanation for a higher association between investment and investment opportunities when market fragmentation is high is that market fragmentation reduces noise in the 
measure of investment opportunities. That is, there is no change in firms' investment but the empirical association between investment and investment opportunities is higher because there is less measurement error in investment opportunities. If this were the sole explanation for the higher association between investment and investment opportunities when market fragmentation is high, we would not expect to observe real effects of market fragmentation. To examine this possibility, we test whether market fragmentation is associated with higher levels of future profitability, controlling for other factors. We do so by estimating the following regression model:

$$
\begin{gathered}
R O A_{t+1} \text { or } \Sigma^{3}{ }_{i=1} R^{R O A_{t+i}}=b_{0}+b_{1} F_{R A G_{t}}+b_{2} R O A_{t}+b_{3} S_{I Z E_{t}} \\
+ \text { Firm Fixed Effects }+ \text { Year Fixed Effects }+e_{t+i},
\end{gathered}
$$

where the dependent variable is net income before extraordinary items divided by total assets, measured either in the subsequent fiscal year or as the sum over the subsequent three fiscal years. If market fragmentation has real effects on investment, then we predict $b_{1}$ is positive.

We also examine whether market fragmentation is associated with the profitability of capital investment decisions by estimating the following model:

$$
\begin{gathered}
R O A_{t+1} \text { or } \Sigma^{3}{ }_{i=1} R O A_{t+i}=b_{0}+b_{1} F R A G_{t}+b_{2} F_{R A G_{t}} \times C A P X_{t}+b_{3} C A P X_{t}+b_{4} R^{2 O A_{t}} \\
+b_{5} \text { SIZE }_{t}+\text { Firm Fixed Effects }+ \text { Year Fixed Effects }+e_{t+i},
\end{gathered}
$$

where $b_{3}$ captures the return on capital expenditures when market fragmentation equals zero, and $b_{2}$ captures the effect of market fragmentation on this return. If market fragmentation leads to more profitable investment decisions, we predict $b_{2}$ is positive.

Table 7 presents findings from the estimation of Equations (9a) and (9b). The findings in Column (1) reveal that, conditional on current performance, one-year-ahead performance increases with market fragmentation. In particular, the coefficient on FRAG is significantly positive (coef. $=0.019, t$-stat $=3.33$ ). The coefficient on FRAG in Column (2) is also positive (coef. $=0.042, t$ stat $=2.13$ ), indicating a similar association between market fragmentation and profitability over 
a longer period. The findings in Columns (3) and (4) reveal that the return on capital investment increases with market fragmentation. Specifically, the coefficient on the interaction between FRAG and CAPX is positive (coef. $=0.001, t$-stat $=2.02$ in Column (3) and coef. $=0.003, t$-stat $=$ 1.69 in Column (4)). The findings presented in Table 7 suggest that market fragmentation has a real effect on firms' profitability, rather than simply decreasing measurement error in Tobin's q. ${ }^{15}$

\subsection{Analyses to Improve the Identification of Market Fragmentation}

We use two empirical approaches to mitigate the possibility that factors causing firms to have more fragmented trading also are associated with the responsiveness of investment to investment opportunities. The first approach is a difference-in-differences analysis around a regulatory change, i.e., the introduction of Reg NMS in 2007, which increased market fragmentation. The second approach uses the number of U.S. trading venues as an instrument for market fragmentation.

We use a four-year window to conduct our analysis of Reg NMS, which includes two years prior to the implementation of Reg NMS in 2007 and two years after, and excludes the year of implementation. First, we test whether the increase in market fragmentation associated with the implementation of Reg NMS results in an increase in the responsiveness of investment to investment opportunities by estimating the following regression:

$$
\begin{aligned}
C A P X_{t} & =b_{0}+b_{1} Q_{t-1}+b_{2} Q_{t-1} \times \text { POST }_{t-1}+b_{3} \text { POST }_{t-1}+b_{4} \text { CF }_{t}+b_{5} \text { RETURN }_{t} \\
& +b_{6} \text { INVASSETS }_{t-1}+\text { Firm Fixed Effects }+ \text { Year Fixed Effects }+e_{t}
\end{aligned}
$$

\footnotetext{
15 Inferences are unchanged when we replace profitability in Eqs. (9a) and (9b) with total factor productivity, calculated following Bennett et al. (2020). In Eq. (9a), the coefficient on total factor productivity is significantly positive for both one-year-ahead $(t$-stat $=1.95)$ and three-year-ahead $(t$-stat $=2.45)$ horizons. In Eq. ( $9 \mathrm{~b})$, the coefficient on the interaction between market fragmentation and total factor productivity is significantly positive for both one-year-ahead $(t$-stat $=2.29)$ and three-year-ahead $(t$-stat $=2.46)$ horizons.
} 
where POST is an indicator variable that equals 1 for the two years after 2007 and 0 otherwise. We predict $b_{2}$ is positive if firms have greater responsiveness of investment to investment opportunities after the implementation of Reg NMS in 2007.

We also estimate alternative versions of Equation (10a) that shift the event year backward and forward by two years. These analyses permit us to assess whether our findings are attributable to Reg NMS rather than underlying trends that affect the sensitivity of investment to investment opportunities independent of Reg NMS. In these tests, we predict $b_{2}$ is zero.

Because the two-year period following Reg NMS coincides with the global financial crisis, we also estimate a version of Equation (10a) that uses a four-quarter event window—two quarters prior to the implementation of Reg NMS is August 2007, and two quarters after, excluding the quarter of implementation. This allows us to distinguish the effects of Reg NMS from the effects of the financial crisis.

The findings in Column (1) of Table 8, Panel A, reveal that the sensitivity of investment to investment opportunities increases following the introduction of Reg NMS. In particular, the coefficient on $Q$ increases by $0.213(t$-stat $=2.31$ ), from 0.792 prior to Reg NMS to 1.005 following Reg NMS.

The findings in Columns (2) and (3) relate to estimations of Equation (10a) in which we shift the sample and POST indicator variable forward or backward by two years. In both cases, we do not observe a significant difference in the sensitivity of investment to investment opportunities, i.e., the coefficients on the interactions of $Q$ and POST are not significantly different from zero.

The inferences based on the findings based on quarterly data in Column (4) are similar to those based on the findings in Column (1). The sensitivity of investment to investment opportunities at the quarterly level $(Q$ coef. $=0.079, t$-stat $=2.83)$ significantly increases following 
Reg NMS $(Q \times P O S T$ coef. $=0.055, t$-stat $=2.74)$. Taken together, the findings in Panel A suggest that the increase in the sensitivity of investment to investment opportunities resulted from an event in 2007 (i.e., Reg NMS) rather than from a general time trend.

Our difference-in-differences test compares the effect of Reg NMS on large firms to that on small firms. Prior research documents that market fragmentation benefits primarily large firms (Degryse et al. 2015, Gresse 2017, Haslag and Ringgenberg 2017). Thus, we use small firms as a control group, and we calculate the effect of Reg NMS on large firms relative to small firms by estimating the following regression:

$$
\begin{aligned}
\text { CAPX }_{t} & =b_{0}+b_{1} Q_{t-1}+b_{2} Q_{t-1} \times \text { POST }_{t-1}+b_{3} Q_{t-1} \times \text { POST }_{t-1} \times \text { LARGE }_{t-1}+b_{4} Q_{t-1} \times \text { LARGE }_{t-1} \\
& +b_{5} \text { POST T }_{t-1} \times \text { LARGE }_{t-1}+b_{6} \text { POST }_{t-1}+b_{7} \text { LARGE }_{t-1}+b_{8} C F_{t}+b_{9} \text { RETURN }_{t} \\
& +b_{10} \text { INVASSETS }_{t-1}+\text { Firm Fixed Effects }+ \text { Year Fixed Effects }+e_{t},
\end{aligned}
$$

where $L A R G E$ is a variable that indicates whether the firm's assets are above the sample median. We predict $b_{3}$ is positive if large firms have a greater change in the sensitivity of investment to investment opportunities than small firms after the implementation of Reg NMS in 2007.

The findings presented in Table 8, Panel B, reveal that the increase in sensitivity of investment to investment opportunities following the introduction of Reg NMS is greater for large firms than for small firms. In particular, the increase in the coefficient on $Q$ is greater for large firms, i.e., the $Q \times P O S T \times L A R G E$ coefficient, 0.542 , is significantly positive $(t$-stat $=2.65)$.

Next, we address endogeneity by removing firm characteristics that may simultaneously affect both market fragmentation and the sensitivity of investment to investment opportunities. We use the number of trading venues in the U.S. as an instrument for $F R A G$, following Haslag and Ringgenberg (2017). ${ }^{16}$ We use a two-stage approach, where the first-stage equations, Equations

\footnotetext{
${ }^{16}$ A valid instrument needs to satisfy two conditions: the relevance condition and the exclusion condition. Regarding the relevance condition, we expect the level of market fragmentation to increase with the number of available trading venues. The exclusion condition requires that the number of markets available for equity trading is related to firm-
} 
(11a) and (11b), regress $F R A G$ and $Q \times F R A G$ on the natural $\log$ of the number of trading venues that exist at year end and its interaction with $Q$, along with the control variables from Equation (11c) to help ensure that coefficient estimates from the estimation of Equation (11c) are consistent (Wooldridge 2002). The second-stage equation, Equation (11c), re-estimates Equation (2a) after replacing $F R A G$ with the predicted values of $F R A G$ and $Q \times F R A G$ from Equations (11a) and (11b):

Stage 1: $F R A G_{t-1}=a_{0}+a_{1} \log (\# V E N U E S)_{t-1}+a_{2} Q_{t-1} \times \log (\# V E N U E S)_{t-1}+a_{3} Q_{t-1}$ $+a_{4} C F_{t}+a_{5}$ RETURN $_{t}+a_{6}$ INVASSETS $_{t-1}+$ Firm Fixed Effects

+ Year Fixed Effects $+e_{t}$,

$$
\begin{aligned}
& Q_{t-1} \times F_{R A G_{t-1}}=a_{0}+a_{1} \log (\# V E N U E S)_{t-1}+a_{2} Q_{t-1} \times \log (\# V E N U E S)_{t-1}+a_{3} Q_{t-1} \\
& \quad+a_{4} C F_{t}+a_{5} \text { RETURN } 3_{t}+a_{6} \text { INVASSETS }_{t-1}+\text { Firm Fixed Effects } \\
& \quad+\text { Year Fixed Effects }+e_{t}
\end{aligned}
$$

Stage 2: $C A P X_{t}=b_{0}+b_{1} Q_{t-1}+b_{2} Q_{t-1} \times$ Pred. FRAGt-1 $+b_{3}$ Pred. FRAG $G_{t-1}+b_{4} C F_{t}$

$+b_{5}$ RETURN $_{t}+b_{6}$ INVASSETS $_{t-1}+$ Firm Fixed Effects

+ Year Fixed Effects $+e$.

$\log (\# V E N U E S)$ is the natural $\log$ of the number of trading venues existing in the U.S. at the end of the firm's fiscal year. In Equation (11a), we expect $b_{1}$ is positive if the level of fragmentation increases with the number of trading venues. Likewise, we expect $b_{2}$ is positive in Equation (11b). As with Equation (2a), we predict $b_{2}$ in Equation (11c) is positive if market fragmentation is associated with an increase in revelatory price efficiency (RPE) that informs either managers or creditors about the firm's investment opportunities. Because Pred. FRAG is estimated with error, when estimating Equation (11c) we bootstrap standard errors based on the empirical distribution of coefficient estimates across 1,000 estimations of the model.

The findings in Column (1) of Table 8, Panel C, relating to the estimation of Equation (11a), reveal that $F R A G$ is increasing in the number of markets (coef. $=0.253, t$-stat $=13.55$ ). The

level capital investment only through fragmentation. We do not expect market centers to open or close based on the investment decisions of individual firms. 
findings in Column (2) reveal that the interaction of $Q$ and FRAG is increasing in the interaction of $Q$ and the number of markets (coef. $=0.040, t$-stat $=7.55$ ). Finally, the results from the secondstage regression presented in Column (3) reveal the same inferences as those based on the findings presented in Table 3. In particular, the coefficient on the interaction between $Q$ and Pred. FRAG is significantly positive (coef. $=1.081, t$-stat $=2.16$ ). The Kleibergen-Paap statistic rejects the null hypothesis that Equation (11c) is underidentified, providing support for the instruments we used in first-stage regressions.

Taken together, the findings presented in Table 8 increase our confidence in the conclusion that market fragmentation leads to improvement in price efficiency that facilitates corporate investment.

\section{Summary and Conclusions}

This study examines how equity market fragmentation affects firms' capital investment decisions. Recent empirical research finds that market fragmentation improves market quality, as reflected by, e.g., lower bid-ask spreads. We examine whether this increase in market quality translates into greater revelatory price efficiency. Market fragmentation can lead to an increase in the sensitivity of capital investment to investment opportunities by leading to prices that reveal with greater precision information to managers, i.e., the managerial channel, or to creditors, i.e., the financing channel, about their firms' investment opportunities.

Findings reveal that the association between capital investment and investment opportunities is increasing in market fragmentation. The sensitivity of investment to investment opportunities increases by $27.4 \%$ across the interquartile range of market fragmentation. These findings are consistent with market fragmentation leading to prices that reveal with greater precision information either to managers or to creditors about the firm's investment opportunities. 
Inferences based on an instrumental variable test and a difference-in-differences test are consistent with those based on our primary findings.

To determine the extent to which one or both of the channels contributes to the increase in sensitivity of capital investment to investment opportunities, we compare the effect of market fragmentation on the sensitivity of investment to investment opportunities for firms with low and high levels of financing constraints. Findings reveal that the effects of market fragmentation on investment increase with financing constraints, thereby providing support for the financing channel. We provide additional evidence regarding the existence of the financing channel by analyzing the relation between market fragmentation and the amount of new loans. We find that market fragmentation is associated with a higher sensitivity of new loans to investment opportunities, which is consistent with market fragmentation alleviating financing constraints. In addition, the effect of market fragmentation is concentrated among loans funded by new lenders, which are likely to have less information about borrowers and therefore benefit more from revelatory price efficiency. We find evidence that the effects of market fragmentation also work through the managerial channel, as the effects are evident when financing constraints are low and are larger in firms whose executives are less informed.

Our findings indicate one mechanism by which market fragmentation increases revelatory price efficiency. Because market fragmentation is associated with increased competition among trading venues and lower trading costs, investors have greater opportunities to benefit from informed trade. Consistent with this notion, we find that market fragmentation is associated with higher levels of information acquisition by investors and stock prices that more fully reflect future earnings news. 
Taken together, our study's findings provide the first empirical evidence in the academic literature of real effects of market fragmentation on corporate decision making. Our results suggest that market fragmentation leads to an improvement in revelatory price efficiency, which informs managers and particularly lenders about a firm's investment opportunities. 


\section{References}

Ackerberg, D. A., Caves, K., Frazer, G., 2015. Identification properties of re- cent production function estimators. Econometrica 83, 2411-2451.

Aitken, M., Chen, H. and Foley, S., 2017. The impact of fragmentation, exchange fees and liquidity provision on market quality. Journal of Empirical Finance, 41, 140-160.

Baker, M., and J. Wurgler, 2002. Market timing and capital structure, Journal of Finance, 57, 132.

Bakke, T.E. and Whited, T.M., 2010. Which firms follow the market? An analysis of corporate investment decisions. The Review of Financial Studies, 23(5), 1941-1980.

Bennett, B., Stulz, R., and Wang, Z. et al., 2020. Does the stock market make firms more productive? Journal of Financial Economics, 136, 281-306.

Berger, A., and Udell, G., 1995, Relationship lending and lines of credit in small firm finance, Journal of Business, 68, 351-381.

Bharath, S. T., Dahiya, S., Saunders, A., and Srinivasan, A., 2009. Lending relationships and loan contract terms. The Review of Financial Studies, 24, 1141-1203.

Biddle, G.C. and Hilary, G., 2006. Accounting quality and firm-level capital investment. The Accounting Review, 81(5), 963-982.

Biddle, G.C., Hilary, G. and Verdi, R.S., 2009. How does financial reporting quality relate to investment efficiency? Journal of Accounting and Economics, 48(2-3), 112-131.

Bond, P., Edmans, A. and Goldstein, I., 2012. The real effects of financial markets. Annual Review of Financial Economics, 4(1), 339-360.

Bond, S.R., Klemm, A., Newton-Smith, R., Syed, M. and Vlieghe, G.W., 2004. The roles of expected profitability, Tobin's $\mathrm{Q}$ and cash flow in econometric models of company investment.

Carhart, M.M., 1997. On persistence in mutual fund performance. The Journal of Finance, 52(1), $57-82$.

Cboe, 2021. U.S. Equities Market Volume Summary.

https://www.cboe.com/us/equities/market_share/. Last accessed September 6, 2021.

Chen, H., L. Cohen, U. Gurun, D. Lou, and C. Malloy. 2019. IQ from IP: Simplifying search in portfolio choice. Working paper.

Chen, D. and Duffie, D., 2021. Market Fragmentation. American Economic Review, Forthcoming. 
Chen, Q., Goldstein, I. and Jiang, W., 2007. Price informativeness and investment sensitivity to stock price. The Review of Financial Studies, 20(3), 619-650.

Chowdhry, B. and Nanda, V., 1991. Multimarket trading and market liquidity. The Review of Financial Studies, 4(3), 483-511.

Chung, K.H. and Chuwonganant, C., 2012. Regulation NMS and market quality. Financial Management, 41(2), 285-317.

Crane, A., K. Crotty, and T. Umar. 2018. Do hedge funds profit from public information? Working paper.

Damodoran, A., and C. H. Liu, 1993. Insider trading as a signal of private information, Review of Financial Studies, 6, 79-119.

De Fontnouvelle, P., Fishe, R.P. and Harris, J.H., 2003. The behavior of bid-ask spreads and volume in options markets during the competition for listings in 1999. The Journal of Finance, 58(6), 2437-2463.

Dechow, P.M. and Dichev, I.D., 2002. The quality of accruals and earnings: The role of accrual estimation errors. The Accounting Review, 77(s-1), 35-59.

Degryse, H., De Jong, F. and Kervel, V.V., 2015. The impact of dark trading and visible fragmentation on market quality. Review of Finance, 19(4), 1587-1622.

Downing, C., Underwood, S., and Xing, Y., 2009. An intraday analysis of the relative informational efficiency of stocks and bonds. Journal of Financial and Quantitative Analysis 44 (5), 1081-1102.

Drake, M., D. Roulstone, and J. Thornock. 2015. The determinants and consequences of information acquisition via EDGAR. Contemporary Accounting Research 32, 1128-1161.

Ettredge, M., S. Kwon, D. Smith, and P. Zarowin. 2005. The impact of SFAS No. 131 business segment data on the market's ability to anticipate future earnings. The Accounting Review 80, $773-$ 804.

Fama, E.F. and French, K.R., 1993. Common risk factors in the returns on stocks and bonds. Journal of Financial Economics, 33, 3-56.

Fama, E.F. and MacBeth, J.D., 1973. Risk, return, and equilibrium: Empirical tests. Journal of Political Economy, 81(3), 607-636.

Fazzari, S., Hubbard, R.G. and Petersen, B., 1988. Investment, financing decisions, and tax policy. The American Economic Review, 78(2), 200-205. 
Félez-Vinas, E., 2017. Market fragmentation, mini flash crashes and liquidity. Working paper.

Fleming, J., Kirby, C., and Ostdiek, 1998. Information and volatility linkages in the stock, bond, and money markets. Journal of Financial Economics 49(1), 111-137.

Foucault, T. and Menkveld, A.J., 2008. Competition for order flow and smart order routing systems. The Journal of Finance, 63(1), 119-158.

Francis, J., LaFond, R., Olsson, P. and Schipper, K., 2005. The market pricing of accruals quality. Journal of Accounting and Economics, 39(2), 295-327.

Gebhardt, W., Hvidkjaer, S., and Swaminathan B., 2005. Stock and bond market interaction: Does momentum spill over? Journal of Financial Economics 75(3), 651-690.

Gibbons, B., P. Iliev, and P. Kalodimos. 2019. Analyst information acquisition via EDGAR. Working paper.

Gresse, C., 2017. Effects of lit and dark market fragmentation on liquidity. Journal of Financial Markets, 35, 1-20.

Hadlock, C.J. and Pierce, J.R., 2010. New evidence on measuring financial constraints: Moving beyond the KZ index. The Review of Financial Studies, 23(5), 1909-1940.

Harris, M., and Raviv, A., 1993. Differences in opinion make a horse race. Review of Financial Studies 6, 473-506.

Haslag, P.H. and Ringgenberg, M., 2017. The causal impact of market fragmentation on liquidity. Working paper.

Hayek, F.A., 1945. The use of knowledge in society. The American Economic Review, 35(4), 519-530.

Hoberg, G. and Maksimovic, V., 2015. Redefining financial constraints: A text-based analysis. The Review of Financial Studies, 28(5), 1312-1352.

Jagolinzer, A. D., Larcker, D. F., and Taylor, D. J., 2011. Corporate governance and the information content of insider trades. Journal of Accounting Research, 49(5), 1249-1274.

Jayaraman, S. and Wu, J.S., 2019. Is silence golden? Real effects of mandatory disclosure. The Review of Financial Studies, 32(6), 2225-2259.

Kaplan, S.N. and Zingales, L., 1997. Do investment-cash flow sensitivities provide useful measures of financing constraints? The Quarterly Journal of Economics, 112(1), 169-215.

Ke, B., S. Huddart, and K. Petroni, 2002. What insiders know about future earnings and how they use it: Evidence from insider trades, Journal of Accounting and Economics, 35, 315-346. 
Lee, C., P. Ma, and C. Wang. 2015. Search-based peer firms: Aggregating investor perceptions through internet co-searches. Journal of Financial Economics 116, 410-431.

Loughran, T., and B. McDonald. 2017. The use of EDGAR filings by investors. Journal of Behavioral Finance 18, 231-248.

Loughran, T., and J. Ritter, 1995. The new issues puzzle, Journal of Finance, 50, 23-51.

Lundholm, R., and L. Myers. 2002. Bringing the future forward: The effect of disclosure on the returns-earnings relation. Journal of Accounting and Economics 40, 809-839.

Malamud, S. and Rostek, M., 2017. Decentralized exchange. American Economic Review, 107(11), 3320-62.

Meulbroek, L. K., 1992. An empirical analysis of illegal insider trading, Journal of Finance, 47 , 1661-1699.

Mendelson, H., 1987. Consolidation, fragmentation, and market performance. Journal of Financial and Quantitative Analysis, 22(2), 189-207.

Myers, S.C. and Majluf, N.S., 1984. Corporate financing and investment decisions when firms have information that investors do not have. Journal of Financial Economics, 13(2), 187-221.

Norden, L., and Weber, M., 2004. Informational efficiency of credit default swap and stock impact of credit rating announcements. Journal of Banking and Finance 28 (11), 2813-2843.

O’Hara, M. and Ye, M., 2011. Is market fragmentation harming market quality? Journal of Financial Economics, 100(3), 459-474.

Osipovich, A., 2018. NYSE Opens Doors to Stocks From Rival Exchanges, Ending Decades-Old Policy. The Wall Street Journal. April 9, 2018.

Pagano, M., 1989. Trading volume and asset liquidity. Quarterly Journal of Economics, 104, 255-274.

Petersen, M. A., and Rajan, R. G., 1994. The benefits of lending relationships: Evidence from small business data, Journal of Finance, 49, 3-37.

Piotroski, J., and D. Roulstone, 2005. Do insider trades reflect both contrarian beliefs and superior knowledge about future cash-flow realizations? Journal of Accounting and Economics, $39,55-81$.

Redfearn, B., 2019. The Nexus of Equity Market Structure and Investor Relations: Remarks at the 2019 Annual Conference of the National Investor Relations Institute. Accessed on November 11, 2019, from https://www.sec.gov/news/speech/speech-redfearn-060319. 
Regulation National Market System, 2005. U.S. Securities and Exchange Commission.

Securities Acts Amendments, 1975. U.S. Securities and Exchange Commission.

Seyhun, H. N., 1992, Why does aggregate insider trading predict future stock returns? Quarterly Journal of Economics, 107, 1303-1331.

Seyhun, H. N., 1998. Investment intelligence from insider trading, MIT Press, Cambridge.

Stoll, H. R., 2001. Market fragmentation. Financial Analysts Journal 57, 16-20.

Tobin, J., 1969. A general equilibrium approach to monetary theory. Journal of Money, Credit and Banking, 1(1), 15-29.

Wooldridge, J., 2002. Econometric Analysis of Cross Section and Panel Data, MIT Press.

Ye, M., Zheng, M., and Zhu, W., 2019. Price Discreteness and Investment to Price Sensitivity. Working paper, University of Illinois at Urbana-Champaign. 


\section{Appendix 1: Variable Definitions}

FRAG

CAPX

$Q$

CF

RETURN3

INVASSETS

SIZE

$M B$

$R O A$

LEVERAGE

IDIOVOL

TURNOVER

ANALYSTS

INSTOWN

NYSE

EDGAR10KQ

EDGAR

RETURN

$\triangle E A R N$

NASDAQ

RKSIZE

RKCONSTR

$R K A Q$

NEWLOANS
1-Herfindahl-Hirschman Index of trade value across all trading venues that exist during the calendar year. FRAG ranges from 0 (no fragmentation) to 1 (high fragmentation).

Capital expenditures as a percentage of beginning-of-year total assets. Tobin's q, equal to the sum of market value of equity and book value of debt, divided by the beginning-of-year book value of total assets. Net operating cash flow as a percentage of beginning-of-year total assets.

The value-weighted, market-adjusted stock return over the current and subsequent two fiscal years.

Inverse of beginning-of-year total assets.

Natural log of total assets.

Market value of equity divided by the book value of equity.

Income before extraordinary items, divided by year-end total assets.

Sum of long-term and short-term debt, divided by the sum of market value of equity and book value of debt.

The variance of the residual obtained by fitting the Carhart (1997) fourfactor model to daily stock returns over the fiscal year.

Natural log of trading volume scaled by the number of shares outstanding.

Natural $\log$ of one plus the number of analysts on $\mathrm{I} / \mathrm{B} / \mathrm{E} / \mathrm{S}$ who issue an earnings forecast during the fiscal year.

Percentage of common shares owned by institutional investors as reported in $13 \mathrm{~F}$ filings.

Indicator equal to 1 if the firm's primary listing venue is the New York Stock Exchange.

The natural $\log$ of the number of the firm's $10-\mathrm{K}$ or $10-\mathrm{Q}$ filings downloaded from EDGAR during the fiscal year, using the SEC's EDGAR $\log$ file.

The natural log of the total number of the firm's filings downloaded from EDGAR during the fiscal year, using the SEC's EDGAR log file. The buy-and-hold stock return over the fiscal year.

Change in annual net income before extraordinary items, scaled by the market value of equity.

Indicator equal to 1 if the firm's primary listing venue is the Nasdaq Stock Market.

Decile rank of total assets, scaled between 0 and 1 .

Decile rank of financing constraints, scaled between 0 and 1. Financing constraints are measured using the Hoberg and Maksimovic (2015) "Delay Investment Score".

Decile rank of negative 1 times the standard deviation of firm-level residuals from the Dechow and Dichev (2002) model over years t-5 to $\mathrm{t}-1$. The variable is scaled between 0 and 1 .

Natural log of the total amount of new loans raised during the year. 
NONREL

RKINSTRADE

\#VENUES
Indicator equal to 1 if the ratio of non-relationship loans to total loans is above the sample median. A loan is considered as relationship lending if the firm borrowed at least once from the same bank within the prior 5 years.

Decile rank of the profitability of insiders' trades, scaled between 0 and 1. The profitability of insiders' trades in year $t$ is measured as the average one-month, Carhart (1997) four-factor risk-adjusted return following each insider's transaction.

Natural log of the number of trading venues existing in the U.S. at the end of the firm's fiscal year. 


\section{Appendix 2: Trading volume across exchanges}

\begin{tabular}{lcccc}
\hline 2017 Trading Volume & $\begin{array}{c}\text { All Stocks } \\
(\mathrm{N}=3,536)\end{array}$ & $\begin{array}{c}\text { NYSE Stocks } \\
(\mathrm{N}=1,304)\end{array}$ & $\begin{array}{c}\text { Nasdaq Stocks } \\
(\mathrm{N}=2,079)\end{array}$ & $\begin{array}{c}\text { Other Stocks } \\
(\mathrm{N}=153)\end{array}$ \\
\hline NYSE & $18.1 \%$ & $30.0 \%$ & $0.0 \%$ & $0.0 \%$ \\
NYSE American & $0.3 \%$ & $0.1 \%$ & $0.1 \%$ & $16.0 \%$ \\
NYSE Arca & $6.0 \%$ & $5.6 \%$ & $6.5 \%$ & $9.7 \%$ \\
National Stock Exchange & $0.0 \%$ & $0.0 \%$ & $0.0 \%$ & $0.1 \%$ \\
Chicago Stock Exchange & $0.4 \%$ & $0.4 \%$ & $0.3 \%$ & $0.1 \%$ \\
Direct Edge A & $1.5 \%$ & $1.5 \%$ & $1.4 \%$ & $1.2 \%$ \\
Direct Edge X & $6.0 \%$ & $5.0 \%$ & $7.5 \%$ & $8.0 \%$ \\
BATS Y & $4.4 \%$ & $4.5 \%$ & $4.4 \%$ & $3.0 \%$ \\
BATS Z & $5.2 \%$ & $5.2 \%$ & $5.2 \%$ & $4.5 \%$ \\
NASDAQ & $17.6 \%$ & $9.3 \%$ & $30.9 \%$ & $8.1 \%$ \\
NASDAQ OMX BX & $3.2 \%$ & $3.1 \%$ & $3.3 \%$ & $1.9 \%$ \\
NASDAQ OMX PSX & $0.6 \%$ & $0.5 \%$ & $0.9 \%$ & $0.3 \%$ \\
Investors Exchange & $2.3 \%$ & $2.4 \%$ & $2.2 \%$ & $1.9 \%$ \\
Off-exchange (FINRA) & $34.5 \%$ & $32.4 \%$ & $37.3 \%$ & $45.4 \%$ \\
\hline
\end{tabular}

Appendix 2 presents the distribution of trades of common shares across trading venues for the calendar year 2017. The 14 trading venues include 13 exchanges and an aggregation of trades from various non-exchange trading venues (e.g., dark pools), which we obtain from FINRA. "NYSE Stocks" ("Nasdaq Stocks") includes only stocks that initially listed on the New York Stock Exchange (Nasdaq Stock Exchange). Stocks that initially listed on another trading venue are included in "Other Stocks". 
Table 1: Statistics on Market Fragmentation

Panel A: Trading venues as of December 31, 2017

\begin{tabular}{clllll}
\hline Code & \multicolumn{1}{c}{ Trading Venue Name } & & Code & & \multicolumn{1}{c}{ Trading Venue Name } \\
\cline { 1 - 2 } \cline { 5 - 6 } A & NYSE MKT Stock Exchange & & $\mathrm{N}$ & & New York Stock Exchange \\
$\mathrm{B}$ & NASDAQ OMX BX Stock Exchange & & $\mathrm{P}$ & & NYSE Arca SM \\
$\mathrm{C}$ & National Stock Exchange & & $\mathrm{Q}$ & & NASDAQ Stock Exchange \\
$\mathrm{D}$ & Off-exchange Trading (from FINRA) & & $\mathrm{V}$ & & The Investors' Exchange \\
$\mathrm{J}$ & Direct Edge A Stock Exchange & & $\mathrm{X}$ & & NASDAQ OMX PSX Stock Exchange \\
$\mathrm{K}$ & Direct Edge X Stock Exchange & & $\mathrm{Y}$ & & BATS Y-Exchange \\
$\mathrm{M}$ & Chicago Stock Exchange & & $\mathrm{Z}$ & BATS Exchange \\
\hline
\end{tabular}

Panel B: Market fragmentation by year

\begin{tabular}{|c|c|c|c|c|c|}
\hline Year & $\begin{array}{c}\text { Number of } \\
\text { Trading Venues }\end{array}$ & $\begin{array}{c}\text { Mean of } \\
F R A G\end{array}$ & Year & $\begin{array}{c}\text { Number of } \\
\text { Trading Venues }\end{array}$ & $\begin{array}{c}\text { Mean of } \\
F R A G\end{array}$ \\
\hline 1995 & 9 & 0.08 & 2007 & 11 & 0.37 \\
\hline 1996 & 9 & 0.08 & 2008 & 11 & 0.53 \\
\hline 1997 & 9 & 0.08 & 2009 & 11 & 0.60 \\
\hline 1998 & 9 & 0.08 & 2010 & 15 & 0.63 \\
\hline 1999 & 9 & 0.09 & 2011 & 14 & 0.66 \\
\hline 2000 & 9 & 0.11 & 2012 & 14 & 0.70 \\
\hline 2001 & 9 & 0.11 & 2013 & 14 & 0.70 \\
\hline 2002 & 10 & 0.10 & 2014 & 14 & 0.69 \\
\hline 2003 & 10 & 0.13 & 2015 & 13 & 0.70 \\
\hline 2004 & 10 & 0.26 & 2016 & 14 & 0.71 \\
\hline 2005 & 10 & 0.36 & 2017 & 14 & 0.72 \\
\hline 2006 & 11 & 0.35 & & & \\
\hline
\end{tabular}

Table 1 reports data on market fragmentation between 1995 to 2017. Panel A displays the trading venues contained in the TAQ database as of December 31, 2017. Panel B reports the number of trading venues and sample mean of market fragmentation across those venues by year. The 14 trading venues include 13 exchanges and an aggregation of trades from various non-exchange trading venues (e.g., dark pools), which we obtain from FINRA. Market fragmentation, FRAG, equals 1 minus the Herfindahl-Hirschman of trade value for every stock executed in each trading venues and ranges from 0 (no fragmentation) to 1 (high fragmentation). 
Table 2: Descriptive Statistics

Panel A: Summary statistics

\begin{tabular}{lrrrrrr}
\hline Variable & \multicolumn{1}{c}{$\mathrm{N}$} & Mean & Std Dev & \multicolumn{1}{c}{$25 \%$} & Median & \multicolumn{1}{c}{$75 \%$} \\
\hline FRAG $_{t-1}$ & 109,020 & 0.35 & 0.29 & 0.03 & 0.30 & 0.64 \\
CAPX $_{t}$ & 109,020 & 5.69 & 7.96 & 1.01 & 3.16 & 7.01 \\
$Q_{t-1}$ & 109,020 & 2.21 & 2.33 & 1.10 & 1.49 & 2.36 \\
CF $_{t}$ & 109,020 & 3.33 & 18.05 & 0.41 & 5.46 & 11.68 \\
RETURN $_{t}$ & 109,020 & 0.03 & 1.10 & -0.60 & -0.12 & 0.37 \\
INVASSETS $_{t-1}$ & 109,020 & 15.03 & 36.02 & 0.50 & 2.42 & 11.51 \\
SIZE $_{t}$ & 109,020 & 6.18 & 2.22 & 4.56 & 6.13 & 7.68 \\
MB $_{t}$ & 109,020 & 0.03 & 0.04 & 0.01 & 0.02 & 0.03 \\
ROA $_{t}$ & 109,020 & -0.02 & 0.20 & -0.02 & 0.03 & 0.07 \\
LEVERAGE $_{t}$ & 109,020 & 0.24 & 0.24 & 0.02 & 0.17 & 0.39 \\
IDIOVOL & 109,020 & 0.03 & 0.02 & 0.02 & 0.03 & 0.04 \\
TURNOVER $_{t}$ & 109,020 & 0.47 & 0.37 & 0.20 & 0.39 & 0.65 \\
ANALYSTS $_{t}$ & 109,020 & 1.49 & 1.12 & 0.00 & 1.61 & 2.40 \\
INSTOWN $_{t}$ & 109,020 & 0.46 & 0.34 & 0.15 & 0.44 & 0.74 \\
NYSE $_{t}$ & 109,020 & 0.38 & 0.49 & 0.00 & 0.00 & 1.00 \\
NASDAQ $_{t}$ & 109,020 & 0.55 & 0.50 & 0.00 & 1.00 & 1.00 \\
EDGARIOKQ $_{t}$ & 56,785 & 2.18 & 1.46 & 1.29 & 1.84 & 2.76 \\
EDGAR $_{t}$ & 56,785 & 3.16 & 1.62 & 2.01 & 2.58 & 3.63 \\
RETURN $_{t}$ & 109,020 & 0.16 & 0.69 & -0.21 & 0.06 & 0.35 \\
EARN $_{t}$ & 109,020 & 0.00 & 0.15 & -0.01 & 0.00 & 0.01 \\
RKSIZE $_{t}$ & 109,020 & 0.50 & 0.32 & 0.22 & 0.56 & 0.78 \\
RKCONSTR $_{t}$ & 51,383 & 0.50 & 0.32 & 0.22 & 0.56 & 0.78 \\
RKAQ $_{t}$ & 72,808 & 0.50 & 0.32 & 0.22 & 0.56 & 0.78 \\
NEWLOANS $_{t}$ & 20,128 & 12.60 & 1.56 & 11.62 & 12.64 & 13.68 \\
NONREL $_{t}$ & 20,128 & 0.35 & 0.45 & 0.00 & 0.00 & 1.00 \\
RKINSTRADE $_{t}$ & 109,020 & 0.50 & 0.32 & 0.22 & 0.44 & 0.78 \\
\#VENUES $_{t}$ & 109,020 & 10.56 & 1.85 & 9.00 & 10.00 & 12.25 \\
\hline
\end{tabular}


Table 2 (continued): Descriptive Statistics

Panel B: Pearson correlations among select variables

\begin{tabular}{|c|c|c|c|c|c|c|c|c|c|c|c|c|c|c|c|}
\hline & $(1)$ & (2) & (3) & (4) & (5) & (6) & (7) & (8) & (9) & (10) & (11) & (12) & (13) & (14) & (15) \\
\hline $1 F R A G_{t-1}$ & 1.00 & & & & & & & & & & & & & & \\
\hline $2 C A P X_{t}$ & -0.13 & 1.00 & & & & & & & & & & & & & \\
\hline $3 Q_{t-1}$ & -0.08 & 0.16 & 1.00 & & & & & & & & & & & & \\
\hline $4 C F_{t}$ & 0.06 & 0.16 & -0.17 & 1.00 & & & & & & & & & & & \\
\hline 5 RETURN $3_{t}$ & -0.02 & -0.04 & -0.06 & 0.11 & 1.00 & & & & & & & & & & \\
\hline 6 INVASSETS $_{t-1}$ & -0.29 & 0.06 & 0.20 & -0.35 & -0.08 & 1.00 & & & & & & & & & \\
\hline $7 \operatorname{SIZE}_{t}$ & 0.44 & -0.05 & -0.18 & 0.29 & 0.03 & -0.59 & 1.00 & & & & & & & & \\
\hline $8 M B_{t}$ & -0.01 & 0.06 & 0.33 & -0.06 & -0.05 & 0.14 & -0.07 & 1.00 & & & & & & & \\
\hline $9 R O A_{t}$ & 0.07 & 0.05 & -0.19 & 0.75 & 0.08 & -0.34 & 0.33 & -0.08 & 1.00 & & & & & & \\
\hline $10 L_{E V E R A G E_{t}}$ & 0.05 & -0.04 & -0.32 & 0.02 & 0.05 & -0.21 & 0.32 & -0.23 & 0.04 & 1.00 & & & & & \\
\hline $11 \mathrm{IDIOVOL}_{t}$ & -0.37 & 0.05 & 0.15 & -0.32 & -0.01 & 0.48 & -0.59 & 0.02 & -0.43 & -0.02 & 1.00 & & & & \\
\hline 12 TURNOVER $_{t}$ & 0.24 & 0.10 & 0.24 & -0.02 & -0.06 & -0.07 & 0.19 & 0.12 & -0.08 & -0.11 & 0.11 & 1.00 & & & \\
\hline 13 ANALYSTS $_{t}$ & 0.35 & 0.08 & 0.12 & 0.21 & 0.02 & -0.38 & 0.58 & 0.09 & 0.17 & -0.08 & -0.37 & 0.40 & 1.00 & & \\
\hline 14 INSTOWN $_{t}$ & 0.33 & -0.01 & 0.01 & 0.23 & 0.04 & -0.37 & 0.45 & 0.04 & 0.21 & -0.05 & -0.40 & 0.32 & 0.55 & 1.00 & \\
\hline 15 \#VENUES $_{t}$ & 0.85 & -0.14 & -0.08 & 0.01 & -0.02 & -0.21 & 0.31 & -0.01 & 0.03 & 0.02 & -0.30 & 0.17 & 0.22 & 0.20 & 1.00 \\
\hline
\end{tabular}




\section{Table 2 (continued): Descriptive Statistics}

Panel C: Firm-level characteristics associated with market fragmentation

$$
\begin{aligned}
& F R A G_{t}=b_{0}+b_{1} S I Z E_{t}+b_{2} M B_{t}+b_{3} R O A_{t}+b_{4} L E V E R A G E_{t}+b_{5} I D I O V O L_{t} \\
& +b_{6} \text { TURNOVER } R_{t}+b_{7} \text { ANALYST }_{t}+b_{8} \text { INSTOWN }_{t}+b_{9} N Y S E_{t} \\
& + \text { b10 NASDAQ } Q_{t}+\text { Industry Fixed Effects }+ \text { Year Fixed Effects }+e_{t}
\end{aligned}
$$

\begin{tabular}{|c|c|c|}
\hline & (1) & (2) \\
\hline$S I Z E_{t}$ & $\begin{array}{c}0.007 * * * \\
(12.44)\end{array}$ & $\begin{array}{c}0.012^{* * * *} \\
(9.50)\end{array}$ \\
\hline$M B_{t}$ & $\begin{array}{l}0.000 \\
(0.02)\end{array}$ & $\begin{array}{c}-0.034 * * * \\
(-3.39)\end{array}$ \\
\hline$R O A_{t}$ & $\begin{array}{c}-0.019 * * * \\
(-7.56)\end{array}$ & $\begin{array}{l}0.005 \\
(1.53)\end{array}$ \\
\hline$L_{E V E R A G E_{t}}$ & $\begin{array}{l}0.004 \\
(1.31)\end{array}$ & $\begin{array}{c}0.030^{* * * *} \\
(7.06)\end{array}$ \\
\hline IDIOVOL $_{t}$ & $\begin{array}{c}-0.006^{* * * *} \\
(-15.84)\end{array}$ & $\begin{array}{c}-0.007 * * * \\
(-20.49)\end{array}$ \\
\hline TURNOVER $_{t}$ & $\begin{array}{c}0.039 * * * \\
(21.99)\end{array}$ & $\begin{array}{c}0.036 * * * \\
(17.03)\end{array}$ \\
\hline ANALYSTS $_{t}$ & $\begin{array}{c}0.016 * * * \\
(19.14)\end{array}$ & $\begin{array}{c}0.008 * * * \\
(6.46)\end{array}$ \\
\hline INSTOWN & $\begin{array}{c}0.026^{* * * *} \\
(9.80)\end{array}$ & $\begin{array}{l}0.010^{* * * *} \\
(3.24)\end{array}$ \\
\hline$N Y S E_{t}$ & $\begin{array}{c}-0.035^{* * *} \\
(-8.87)\end{array}$ & $\begin{array}{c}-0.025^{* * * *} \\
(-4.12)\end{array}$ \\
\hline$N A S D A Q_{t}$ & $\begin{array}{c}-0.097 * * * \\
(-26.48)\end{array}$ & $\begin{array}{c}-0.108 * * * \\
(-18.98)\end{array}$ \\
\hline Fixed Effects & Industry, Year & Firm, Year \\
\hline $\begin{array}{l}\text { \# Observations } \\
\text { Adjusted } \mathrm{R}^{2}\end{array}$ & $\begin{array}{c}109,020 \\
0.879\end{array}$ & $\begin{array}{c}109,020 \\
0.916\end{array}$ \\
\hline
\end{tabular}

Table 2 presents descriptive statistics for the sample. Panel A presents summary statistics, Panel B presents Pearson correlations among variables, and Panel C reports pooled OLS regression results from the estimation of Eq. (1) - a regression of market fragmentation onto various firm characteristics. $t$-statistics based on standard errors clustered by firm are shown in parentheses. $* * *, * *$, and $*$ denote significance at the $0.01,0.05$, and 0.10 levels, respectively. Variable definitions are provided in Appendix 1. 
Table 3: Fragmentation and the Sensitivity of Investment to Investment Opportunities

$$
\begin{aligned}
& C A P X_{t}=b_{0}+b_{1} Q_{t-1}+b_{2} Q_{t-1} \times F R A G_{t-1}+b_{3} F R A G_{t-1}+b_{4} C_{t}+b_{5} \text { RETURN3 }_{t} \\
& +b_{6} \text { INVASSETS }_{t-1}+\text { Firm Fixed Effects }+ \text { Year Fixed Effects }+e_{t} \\
& C A P X_{t}=b_{0}+b_{1} Q_{t-1}+b_{2} Q_{t-1} \times F R A G_{t-1}+b_{3} Q_{t-1} \times F R A G_{t-1} \times R K S I Z E_{t-1} \\
& +b_{4} Q_{t-1} \times R K S I Z E_{t-1}+b_{5} F R A G_{t-1} \times R K S I Z E_{t-1}+b_{6} F R A G_{t-1}+b_{7} R K S I Z E_{t-1} \\
& +b_{8} C_{t}+b_{9} \text { RETURN }_{t}+b_{10} \text { INVASSETS }_{t-1}+\text { Firm Fixed Effects } \\
& + \text { Year Fixed Effects }+e_{t}
\end{aligned}
$$

\begin{tabular}{|c|c|c|c|}
\hline & (1) & (2) & (3) \\
\hline$Q_{t-1}$ & $\begin{array}{c}0.588 * * * \\
(24.41)\end{array}$ & $\begin{array}{c}0.548 * * * \\
(20.05)\end{array}$ & $\begin{array}{c}0.530 * * * \\
(11.40)\end{array}$ \\
\hline$Q_{t-1} \times F R A G_{t-1}$ & & $\begin{array}{c}0.248 * * * \\
(3.45)\end{array}$ & $\begin{array}{l}0.007 \\
(0.07)\end{array}$ \\
\hline$Q_{t-1} \times F R A G_{t-1} \times R K S I Z E_{t-1}$ & & & $\begin{array}{c}0.871 * * * \\
(3.34)\end{array}$ \\
\hline$Q_{t-1} \times R K S I Z E_{t-1}$ & & & $\begin{array}{l}-0.026 \\
(-0.26)\end{array}$ \\
\hline$F R A G_{t-1} \times R K S I Z E_{t-1}$ & & & $\begin{array}{l}0.756 \\
(1.23)\end{array}$ \\
\hline$F R A G_{t-1}$ & & $\begin{array}{c}-2.888 * * * \\
(-8.63)\end{array}$ & $\begin{array}{c}-3.112 * * * \\
(-6.69)\end{array}$ \\
\hline$R K S I Z E_{t-1}$ & & & $\begin{array}{c}-7.849 * * * \\
(-16.80)\end{array}$ \\
\hline$C F_{t}$ & $\begin{array}{c}0.033 * * * \\
(10.12)\end{array}$ & $\begin{array}{c}0.032 * * * \\
(9.93)\end{array}$ & $\begin{array}{c}0.029 * * * \\
(8.91)\end{array}$ \\
\hline RETURN3 ${ }_{t}$ & $\begin{array}{c}-0.294 * * * \\
(-10.69)\end{array}$ & $\begin{array}{c}-0.301 * * * \\
(-11.00)\end{array}$ & $\begin{array}{c}-0.388 * * * \\
(-14.32)\end{array}$ \\
\hline$I_{N V A S S E T S}{ }_{t-1}$ & $\begin{array}{c}0.021 * * * \\
(8.38)\end{array}$ & $\begin{array}{c}0.021 * * * \\
(8.33)\end{array}$ & \\
\hline Firm \& Year Fixed Effects & Yes & Yes & Yes \\
\hline $\begin{array}{l}\text { \# Observations } \\
\text { Adjusted } \mathrm{R}^{2}\end{array}$ & $\begin{array}{c}109,020 \\
0.591 \\
\end{array}$ & $\begin{array}{c}109,020 \\
0.592 \\
\end{array}$ & $\begin{array}{c}109,020 \\
0.596 \\
\end{array}$ \\
\hline
\end{tabular}


Table 3 reports pooled OLS regression results from the estimation of Eqs. (2a) and (2b). CAPX is capital expenditures as a percentage of total assets. $Q$ is Tobin's q. $C F$ is cash flow from operations as a percentage of total assets. FRAG equals one minus the Herfindahl-Hirschman Index measure of the concentration of trading across trading venues during the fiscal year. RKSIZE is the decile rank of the firm's total assets, scaled between 0 and 1 . All other variables are defined in Appendix 1. $t$-statistics based on standard errors clustered by firm are shown in parentheses. $* * *, * *$, and $*$ denote significance at the $0.01,0.05$, and 0.10 levels, respectively. 
Table 4: How Market Fragmentation Improves Revelatory Price Efficiency

Panel A: EDGAR downloads

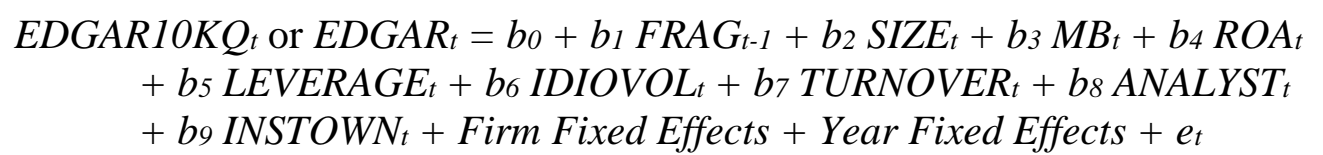

\begin{tabular}{|c|c|c|}
\hline & $(1)$ & (2) \\
\hline Dependent Variable $=$ & $\# E D G A R 10 K Q_{t}$ & $\# E D G A R_{t}$ \\
\hline$F R A G_{t-1}$ & $\begin{array}{c}0.114 * * * \\
(2.69)\end{array}$ & $\begin{array}{c}0.150 * * * \\
(5.93)\end{array}$ \\
\hline$S I Z E_{t}$ & $\begin{array}{c}0.116^{* * * *} \\
(8.97)\end{array}$ & $\begin{array}{c}0.153 * * * \\
(22.75)\end{array}$ \\
\hline$M B_{t}$ & $\begin{array}{c}0.129^{*} \\
(1.70)\end{array}$ & $\begin{array}{l}0.063 \\
(1.20)\end{array}$ \\
\hline$R O A_{t}$ & $\begin{array}{c}-0.116^{* * * *} \\
(-3.99)\end{array}$ & $\begin{array}{c}-0.248^{* * *} \\
(-14.18)\end{array}$ \\
\hline LEVERAGE $E_{t}$ & $\begin{array}{c}-0.098 * * * \\
(-2.83)\end{array}$ & $\begin{array}{c}-0.076^{* * * *} \\
(-3.66)\end{array}$ \\
\hline$I_{\text {IDIOVOL }}$ & $\begin{array}{l}0.204 \\
(0.69)\end{array}$ & $\begin{array}{c}1.291 * * * \\
(6.69)\end{array}$ \\
\hline TURNOVER $R_{t}$ & $\begin{array}{c}0.187 * * * \\
(8.47)\end{array}$ & $\begin{array}{c}0.271 * * * \\
(23.57)\end{array}$ \\
\hline ANALYSTS $_{t}$ & $\begin{array}{c}0.021^{*} \\
(1.93)\end{array}$ & $\begin{array}{c}-0.015^{* * * *} \\
(-2.61)\end{array}$ \\
\hline$I_{N S T O W N}$ & $\begin{array}{c}0.088 * * * \\
(4.49)\end{array}$ & $\begin{array}{c}-0.023^{*} \\
(-1.86)\end{array}$ \\
\hline Firm \& Year Fixed Effects & Yes & Yes \\
\hline \# Observations & 56,785 & 56,785 \\
\hline Adjusted $\mathrm{R}^{2}$ & 0.918 & 0.970 \\
\hline
\end{tabular}




\section{Table 4 (continued): How Market Fragmentation Improves Revelatory Price Efficiency}

Panel B: Future earnings response coefficients

$$
\begin{aligned}
\text { RETURN }_{t} & =b_{0}+b_{1} \Delta E A R N_{t}+b_{2} \triangle E A R N_{t+1}+b_{3} \Delta E A R N_{t} \times F R A G_{t-1}+b_{4} \Delta E A R N_{t+1} \times F R A G_{t-1} \\
& +b_{5} \text { FRAG }_{t-1}+b_{6} \text { RETURN }_{t+1}+b_{7} \text { RETURN } N_{t-1}+b_{8} S I Z E_{t-1}+b_{9} M B_{t-1} \\
& + \text { Firm Fixed Effects }+ \text { Year Fixed Effects }+e_{t}
\end{aligned}
$$

\begin{tabular}{|c|c|}
\hline$\triangle E A R N_{t}$ & $\begin{array}{l}0.383 * * * \\
(4.29)\end{array}$ \\
\hline$\Delta E A R N_{t+1}$ & $\begin{array}{l}-0.042 \\
(-1.38)\end{array}$ \\
\hline$\Delta E A R N_{t} \times F R A G_{t-1}$ & $\begin{array}{l}0.035 \\
(0.25)\end{array}$ \\
\hline$\Delta E A R N_{t+1} \times F R A G_{t-1}$ & $\begin{array}{c}0.228 * * * \\
(3.05)\end{array}$ \\
\hline$F R A G_{t-1}$ & $\begin{array}{l}-0.202 \\
(-1.55)\end{array}$ \\
\hline$R E T U R N_{t+1}$ & $\begin{array}{c}-0.092 * * \\
(-2.45)\end{array}$ \\
\hline$R E T U R N_{t-1}$ & $\begin{array}{c}-0.159 * * * \\
(-4.47)\end{array}$ \\
\hline$S I Z E_{t-1}$ & $\begin{array}{c}-0.279 * * * \\
(-7.18)\end{array}$ \\
\hline$M B_{t-1}$ & $\begin{array}{c}-1.303 * * * \\
(-5.87)\end{array}$ \\
\hline Firm \& Year Fixed Effects & Yes \\
\hline $\begin{array}{l}\text { \# Observations } \\
\text { Adjusted } \mathrm{R}^{2}\end{array}$ & $\begin{array}{c}109,020 \\
0.196\end{array}$ \\
\hline
\end{tabular}

Table 4 reports pooled OLS regression results from the estimation of Eqs. (3) and (4). FRAG equals one minus the Herfindahl-Hirschman Index measure of the concentration of trading across trading venues during the fiscal year. In Panel A, EDGARIOKQ (EDGAR) is the natural log of the number of downloads of the firm's 10-K and 10-Q filings (all filings) during the fiscal year. In Panel B, RETURN is the firm's buy-and-hold stock return over the fiscal year. $\triangle E A R N$ is the change in net income before extraordinary items scaled by equity market value. All other variables are defined in Appendix 1. $t$-statistics based on standard errors clustered by firm are shown in parentheses. $* * *, * *$, and $*$ denote significance at the 0.01 , 0.05 , and 0.10 levels, respectively. 


\section{Table 5: Evidence for the Financing Channel}

Panel A: Cross-sectional analysis based on the level of financing constraints

$$
\begin{aligned}
\text { CAPX }_{t} & =b_{0}+b_{1} Q_{t-1}+b_{2} Q_{t-1} \times F_{R A G_{t-1}}+b_{3} Q_{t-1} \times F_{R A G_{t-1}} \times \text { RKCONSTR }_{t-1} \\
& +b_{4} Q_{t-1} \times \text { RKCONSTR }_{t-1}+b_{5} \text { FRAG }_{t-1} \times \text { RKCONSTR R }_{t-1}+b_{6} \text { FRAG }_{t-1} \\
& +b_{7} \text { RKCONSTR } \text { RKI }_{t-1}+b_{8} \text { RETURN }_{t}+b_{9} \text { INVASSETS }_{t-1}+\text { Firm Fixed Effects } \\
& + \text { Year Fixed Effects }+e_{t}
\end{aligned}
$$

\begin{tabular}{|c|c|}
\hline$Q_{t-1}$ & $\begin{array}{c}0.504 * * * \\
(9.71)\end{array}$ \\
\hline$Q_{t-1} \times F R A G_{t-1}$ & $\begin{array}{c}0.202^{*} \\
(1.84)\end{array}$ \\
\hline$Q_{t-1} \times F R A G_{t-1} \times R K C O N S T R_{t-1}$ & $\begin{array}{c}0.332^{*} \\
(1.92)\end{array}$ \\
\hline$Q_{t-1} \times R_{K C O N S T R}{ }_{t-1}$ & $\begin{array}{c}-0.149 * * \\
(-2.26)\end{array}$ \\
\hline$F R A G_{t-1} \times R K C O N S T R_{t-1}$ & $\begin{array}{c}-2.009 * * * \\
(-4.06)\end{array}$ \\
\hline$F R A G_{t-1}$ & $\begin{array}{c}-1.688 * * * \\
(-4.53)\end{array}$ \\
\hline$R_{K C O N S T R}-1$ & $\begin{array}{c}0.934 * * * \\
(4.07)\end{array}$ \\
\hline$C F_{t}$ & $\begin{array}{c}0.034 * * * \\
(11.37)\end{array}$ \\
\hline$R E T U R N 3_{t}$ & $\begin{array}{c}-0.387 * * * \\
(-13.54)\end{array}$ \\
\hline INVASSETS $_{t-1}$ & $\begin{array}{c}0.033 * * * \\
(10.34)\end{array}$ \\
\hline Firm \& Year Fixed Effects & Yes \\
\hline \# Observations & 51,383 \\
\hline Adjusted $\mathrm{R}^{2}$ & 0.610 \\
\hline
\end{tabular}


Table 5 (continued): Evidence for the Financing Channel

Panel B: Cross-sectional analysis based on accounting quality

$$
\begin{aligned}
C A P X_{t} & =b_{0}+b_{1} Q_{t-1}+b_{2} Q_{t-1} \times F R A G_{t-1}+b_{3} Q_{t-1} \times F R A G_{t-1} \times R K A Q_{t-1} \\
& +b_{4} Q_{t-1} \times R K A Q_{t-1}+b_{5} F R A G_{t-1} \times R K A Q_{t-1}+b_{6} F R A G_{t-1}+b_{7} R_{R A Q_{t-1}}+b_{8} C F_{t} \\
& +b_{9} \text { RETURN3 }_{t}+b_{10} \text { INVASSETS } \\
& \text { INEFrm Fixed Effects }+ \text { Year Fixed Effects }+e_{t}
\end{aligned}
$$

\begin{tabular}{|c|c|}
\hline$Q_{t-1}$ & $\begin{array}{c}0.600 * * * \\
(7.30)\end{array}$ \\
\hline$Q_{t-1} \times F R A G_{t-1}$ & $\begin{array}{c}1.086^{* * *} * \\
(5.23)\end{array}$ \\
\hline$Q_{t-1} \times F R A G_{t-1} \times R K A Q_{t-1}$ & $\begin{array}{c}-1.280 * * * \\
(-5.12)\end{array}$ \\
\hline$Q_{t-1} \times R K A Q_{t-1}$ & $\begin{array}{l}0.019 \\
(0.16)\end{array}$ \\
\hline$F R A G_{t-1} \times R K A Q_{t-1}$ & $\begin{array}{c}1.421 * * \\
(2.34)\end{array}$ \\
\hline$F R A G_{t-1}$ & $\begin{array}{c}-3.523 * * * \\
(-6.95)\end{array}$ \\
\hline$R K A Q_{t-1}$ & $\begin{array}{c}0.677 * * \\
(2.20)\end{array}$ \\
\hline$C F_{t}$ & $\begin{array}{c}0.038 * * * \\
(10.02)\end{array}$ \\
\hline$R E T U R N 3_{t}$ & $\begin{array}{c}-0.248 * * * \\
(-8.37)\end{array}$ \\
\hline INVASSETS $_{t-1}$ & $\begin{array}{c}0.019 * * * \\
(5.85)\end{array}$ \\
\hline Firm \& Year Fixed Effects & Yes \\
\hline \# Observations & 72,808 \\
\hline Adjusted $\mathrm{R}^{2}$ & 0.584 \\
\hline
\end{tabular}


Table 5 (continued): Evidence for the Financing Channel

Panel C: Market fragmentation and the sensitivity of loans to investment opportunities

$$
\begin{aligned}
& N E W L O A N S_{t}=b_{0}+b_{1} Q_{t-1}+b_{2} Q_{t-1} \times F R A G_{t-1}+b_{3} Q_{t-1} \times F R A G_{t-1} \times N O N R E L_{t-1} \\
& +b_{4} Q_{t-1} \times N O N R E L_{t-1}+b_{5} F R A G_{t-1} \times N O N R E L_{-1}+b_{6} N O N R E L_{t-1}+b_{7} F R A G_{t-1} \\
& +b_{8} \text { SIZE }_{t-1}+b_{9} R_{\text {ROA }}+1+b_{10} L_{\text {LVERAGE }}+1+b_{11} \text { IDIOVOL }_{t-1}+b_{12} \text { ANALYST }_{t-1} \\
& +b_{13} \text { INSTOWN }_{t-1}+\text { Firm Fixed Effects }+ \text { Year Fixed Effects }+e_{t}
\end{aligned}
$$

\begin{tabular}{|c|c|c|}
\hline & (1) & (2) \\
\hline$Q_{t-1}$ & $\begin{array}{l}0.003 \\
(0.47)\end{array}$ & $\begin{array}{l}0.010 \\
(1.30)\end{array}$ \\
\hline$Q_{t-1} \times F R A G_{t-1}$ & $\begin{array}{c}0.075^{* * *} \\
(4.05)\end{array}$ & $\begin{array}{c}0.052^{* * *} \\
(2.37)\end{array}$ \\
\hline$Q_{t-1} \times F R A G_{t-1} \times N O N R E L_{t-1}$ & & $\begin{array}{c}0.134 * * \\
(2.22)\end{array}$ \\
\hline$Q_{t-1} \times N O N R E L_{t-1}$ & & $\begin{array}{c}-0.047 * * \\
(-2.07)\end{array}$ \\
\hline$F R A G_{t-1} \times N O N R E L_{t-1}$ & & $\begin{array}{l}-0.119 \\
(-1.01)\end{array}$ \\
\hline NONRELt-1 & & $\begin{array}{l}-0.005 \\
(-0.09)\end{array}$ \\
\hline$F R A G_{t-1}$ & $\begin{array}{c}-0.400 * * * \\
(-3.91)\end{array}$ & $\begin{array}{c}-0.407 * * * \\
(-3.77)\end{array}$ \\
\hline$S I Z E_{t-1}$ & $\begin{array}{c}0.475 * * * \\
(21.51)\end{array}$ & $\begin{array}{c}0.471 * * * \\
(21.27)\end{array}$ \\
\hline$R O A_{t-1}$ & $\begin{array}{c}0.18218 \\
(1.29)\end{array}$ & $\begin{array}{l}0.190 \\
(1.35)\end{array}$ \\
\hline$L E V E R A G E_{t-1}$ & $\begin{array}{c}-0.297 * * * \\
(-3.60)\end{array}$ & $\begin{array}{c}-0.305^{* * *} \\
(-3.70)\end{array}$ \\
\hline$I D I O V O L_{t-1}$ & $\begin{array}{c}-3.594 * * * \\
(-3.16)\end{array}$ & $\begin{array}{c}-3.445 * * * \\
(-3.03)\end{array}$ \\
\hline$A N A L Y S T_{t-1}$ & $\begin{array}{c}0.044 * * \\
(2.38)\end{array}$ & $\begin{array}{c}0.043 * * \\
(2.29)\end{array}$ \\
\hline$I_{N S T O W N}$ & $\begin{array}{l}0.025 \\
(0.84)\end{array}$ & $\begin{array}{l}0.023 \\
(0.78)\end{array}$ \\
\hline Firm \& Year Fixed Effects & Yes & Yes \\
\hline $\begin{array}{l}\text { \# Observations } \\
\text { Adjusted } \mathrm{R}^{2}\end{array}$ & $\begin{array}{c}20,128 \\
0.750\end{array}$ & $\begin{array}{c}20,128 \\
0.751\end{array}$ \\
\hline
\end{tabular}


Table 5 reports pooled OLS regression results from the estimation of Eqs. (5), (6), and (7). In Panels A and $\mathrm{B}, C A P X$ is capital expenditures as a percentage of total assets. $Q$ is Tobin's q. $C F$ is cash flow from operations as a percentage of total assets. FRAG equals one minus the Herfindahl-Hirschman Index measure of the concentration of trading across trading venues during the fiscal year. RKCONSTR is the decile rank of the Kaplan and Zingales (1997) index of financial constraints updated following Hadlock and Pierce (2010), and $R K A Q$ is the decile rank of the Dechow and Dichev (2002) earnings quality measure, as calculated by Francis et al. (2005). RKCONSTR and $R K A Q$ are scaled between 0 and 1. In Panel C, NEWLOANS is the natural $\log$ of the total dollar amount of new loans obtained during the fiscal year. NONREL equals 1 if the ratio of non-relationship loans to total loans during the year is above the sample median, and 0 otherwise. Following Bharath et al. (2009), we identify a loan as relationship-based if the firm borrowed from the same creditor at least once during the previous five years. All other variables are defined in Appendix 1. $t$-statistics based on standard errors clustered by firm are shown in parentheses. ***, $* *$, and $*$ denote significance at the $0.01,0.05$, and 0.10 levels, respectively. 


\section{Table 6: Evidence for the Managerial Channel}

$$
\begin{aligned}
& C A P X_{t}=b_{0}+b_{1} Q_{t-1}+b_{2} Q_{t-1} \times F R A G_{t-1}+b_{3} Q_{t-1} \times F R A G_{t-1} \times \text { RKINSTRADE }_{t-1} \\
& +b_{4} Q_{t-1} \times \text { RKINSTRADE } E_{t-1}+b_{5} \text { FRAG }_{t-1} \times \text { RKINSTRADE }_{t-1}+b_{6} \text { FRAG }_{t-1} \\
& +b_{7} \text { RKINSTRADE }_{t-1}+b_{8} C_{t}+b_{9} \text { RETURN }_{t}+b_{10} \text { INVASSETS }_{t-1} \\
& + \text { Firm Fixed Effects }+ \text { Year Fixed Effects }+e_{t}
\end{aligned}
$$

\begin{tabular}{|c|c|}
\hline$Q_{t-1}$ & $\begin{array}{c}0.470 * * * \\
(15.44)\end{array}$ \\
\hline$Q_{t-1} \times F R A G_{t-1}$ & $\begin{array}{c}0.391 * * * \\
(4.39)\end{array}$ \\
\hline$Q_{t-1} \times F R A G_{t-1} \times R K I N S T R A D E_{t-1}$ & $\begin{array}{c}-0.363 * * * \\
(-2.59)\end{array}$ \\
\hline$Q_{t-1} \times R K I N S T R A D E_{t-1}$ & $\begin{array}{c}0.261 * * * \\
(3.76)\end{array}$ \\
\hline$F R A G_{t-1} \times R K I N S T R A D E_{t-1}$ & $\begin{array}{c}1.393 * * * \\
(4.10)\end{array}$ \\
\hline$F R A G_{t-1}$ & $\begin{array}{c}-3.521 * * * \\
(-9.55)\end{array}$ \\
\hline$R K I N S T R A D E_{t-1}$ & $\begin{array}{c}-0.873 * * * \\
(-5.35)\end{array}$ \\
\hline$C F_{t}$ & $\begin{array}{c}0.033 * * * \\
(10.10)\end{array}$ \\
\hline$R E T U R N 3_{t}$ & $\begin{array}{c}-0.300 * * * \\
(-10.94)\end{array}$ \\
\hline INVASSETS $_{t-1}$ & $\begin{array}{c}0.020 * * * \\
(8.01)\end{array}$ \\
\hline Firm \& Year Fixed Effects & Yes \\
\hline \# Observations & 109,020 \\
\hline Adjusted $\mathrm{R}^{2}$ & 0.592 \\
\hline
\end{tabular}

Table 6 reports pooled OLS regression results from the estimation of Eq. (8). CAPX is capital expenditures as a percentage of total assets. $Q$ is Tobin's q. $C F$ is cash flow from operations as a percentage of total assets. FRAG equals one minus the Herfindahl-Hirschman Index measure of the concentration of trading across trading venues during the fiscal year. RKINSTRADE is the decile rank of the profitability of insider trades made by the firm's executives during the year, scaled between 0 and 1 . All other variables are defined in Appendix 1.t-statistics based on standard errors clustered by firm are shown in parentheses. ***, **, and $*$ denote significance at the $0.01,0.05$, and 0.10 levels, respectively. 
Table 7: Market Fragmentation and Future Performance

$$
\begin{aligned}
& R O A_{t+1} \text { or } \Sigma^{3}{ }_{i=1} R O A_{t+i}=b_{0}+b_{1} F R A G_{t}+b_{2} R O A_{t}+b_{3} S I Z E_{t} \\
& + \text { Firm Fixed Effects }+ \text { Year Fixed Effects }+e_{t+i} \\
& R O A_{t+1} \text { or } \Sigma_{i=1}^{3} R O A_{t+i}=b_{0}+b_{1} F R A G_{t}+b_{2} F R A G_{t} \times C A P X_{t}+b_{3} C A P X_{t}+b_{4} R O A_{t} \\
& +b_{5} S I Z E_{t}+\text { Firm Fixed Effects }+ \text { Year Fixed Effects }+e_{t+i}
\end{aligned}
$$

\begin{tabular}{|c|c|c|c|c|}
\hline & $(1)$ & $(2)$ & $(3)$ & (4) \\
\hline Dependent Variable $=$ & $R O A_{t+1}$ & $\Sigma_{i=1}^{3} R O A_{t+i}$ & $R O A_{t+1}$ & $\Sigma_{i=1}^{3} R O A_{t+i}$ \\
\hline$F R A G_{t}$ & $\begin{array}{c}0.019 * * * \\
(3.33)\end{array}$ & $\begin{array}{c}0.042 * * \\
(2.13)\end{array}$ & $\begin{array}{c}0.016 * * \\
(2.55)\end{array}$ & $\begin{array}{l}0.033 \\
(1.52)\end{array}$ \\
\hline$F R A G_{t} \times C A P X_{t}$ & & & $\begin{array}{c}0.001 * * \\
(2.02)\end{array}$ & $\begin{array}{c}0.003 * \\
(1.69)\end{array}$ \\
\hline$C A P X_{t}$ & & & $\begin{array}{l}0.000 \\
(1.19)\end{array}$ & $\begin{array}{l}-0.000 \\
(-0.46)\end{array}$ \\
\hline$R O A_{t}$ & $\begin{array}{c}0.143 * * * \\
(3.54)\end{array}$ & $\begin{array}{c}0.258 * * * \\
(2.75)\end{array}$ & $\begin{array}{c}0.142 * * * \\
(3.54)\end{array}$ & $\begin{array}{c}0.258 * * * \\
(2.75)\end{array}$ \\
\hline$S I Z E_{t}$ & $\begin{array}{c}-0.008 * * * \\
(-3.19)\end{array}$ & $\begin{array}{c}-0.030 * * * \\
(-4.54)\end{array}$ & $\begin{array}{c}-0.008 * * * \\
(-3.32)\end{array}$ & $\begin{array}{c}-0.033 * * * \\
(-4.60)\end{array}$ \\
\hline Firm \& Year Fixed Effects & Yes & Yes & Yes & Yes \\
\hline \# Observations & 101,096 & 83,154 & 101,096 & 83,154 \\
\hline Adjusted $\mathrm{R}^{2}$ & 0.570 & 0.700 & 0.570 & 0.700 \\
\hline
\end{tabular}

Table 7 reports pooled OLS regression results from the estimation of Eqs. (9a) and (9b). Results from Eq. (9a) are reported in Columns (1) and (2), and results from Eq. (9b) are reported in Columns (3) and (4). $R O A$ is net income before extraordinary items divided by total assets, FRAG equals one minus the Herfindahl-Hirschman Index measure of the concentration of trading across trading venues during the fiscal year, CAPX is capital expenditures as a percentage of total assets, and SIZE is the natural log of total assets. $t$-statistics based on standard errors clustered by firm are shown in parentheses. $* * *, * *$, and $*$ denote significance at the $0.01,0.05$, and 0.10 levels, respectively. 
Table 8: Analyses Addressing Alternative Explanations

Panel A: Analysis around Reg NMS

CAPX $_{t}=b_{0}+b_{1} Q_{t-1}+b_{2} Q_{t-1} \times$ POST $_{t-1}+b_{3}$ POST $_{t-1}+b_{4} C_{t}+b_{5}$ RETURN3 $_{t}$

$+b_{6}$ INVASSETS $_{t-1}+$ Firm Fixed Effects + Year Fixed Effects $+e_{t}$

\begin{tabular}{|c|c|c|c|c|}
\hline & (1) & (2) & (3) & (4) \\
\hline & $\begin{array}{c}2007 \pm 2 \\
\text { years }\end{array}$ & $\begin{array}{c}\text { Placebo Test } \\
2005 \pm 2 \\
\text { years }\end{array}$ & $\begin{array}{c}\text { Placebo Test } \\
2009 \pm 2 \\
\text { years }\end{array}$ & $\begin{array}{c}2007 \pm 2 \\
\text { quarters }\end{array}$ \\
\hline$Q_{t-1}$ & $\begin{array}{c}0.792 * * * \\
(8.75)\end{array}$ & $\begin{array}{c}0.589 * * * \\
(7.35)\end{array}$ & $\begin{array}{c}0.824 * * * \\
(8.65)\end{array}$ & $\begin{array}{c}0.079 * * * \\
(2.83)\end{array}$ \\
\hline$Q_{t-1} \times P O S T_{t-1}$ & $\begin{array}{c}0.213^{* *} \\
(2.31)\end{array}$ & $\begin{array}{l}0.064 \\
(0.76)\end{array}$ & $\begin{array}{l}-0.080 \\
(-1.01)\end{array}$ & $\begin{array}{c}0.055 * * * \\
(2.74)\end{array}$ \\
\hline$P O S T_{t-1}$ & $\begin{array}{c}-1.185^{* * *} \\
(-3.26)\end{array}$ & $\begin{array}{c}-0.777 * * \\
(-2.07)\end{array}$ & $\begin{array}{l}-0.333 \\
(-0.98)\end{array}$ & $\begin{array}{c}-0.280^{*} \\
(-1.92)\end{array}$ \\
\hline$C F_{t}$ & $\begin{array}{c}0.031 * * * \\
(4.22)\end{array}$ & $\begin{array}{c}0.020 * * * \\
(2.63)\end{array}$ & $\begin{array}{c}0.026 * * * \\
(3.90)\end{array}$ & $\begin{array}{l}-0.008 \\
(-0.67)\end{array}$ \\
\hline RETURN3 ${ }_{t}$ & $\begin{array}{c}-0.267 * * * \\
(-2.69)\end{array}$ & $\begin{array}{c}-0.271 * * * \\
(-3.57)\end{array}$ & $\begin{array}{l}-0.087 \\
(-1.41)\end{array}$ & $\begin{array}{c}-0.075^{*} \\
(-1.65)\end{array}$ \\
\hline INVASSETS $_{t-1}$ & $\begin{array}{c}0.051 * * * \\
(3.88)\end{array}$ & $\begin{array}{c}0.034 * * * \\
(2.98)\end{array}$ & $\begin{array}{c}0.057 * * * \\
(4.75)\end{array}$ & $\begin{array}{l}0.001 \\
(0.05)\end{array}$ \\
\hline $\begin{array}{l}\text { Firm \& Year Fixed Effects } \\
\text { Firm \& Year-Quarter Fixed } \\
\text { Effects }\end{array}$ & $\begin{array}{l}\text { Yes } \\
\text { No }\end{array}$ & $\begin{array}{l}\text { Yes } \\
\text { No }\end{array}$ & $\begin{array}{l}\text { Yes } \\
\text { No }\end{array}$ & $\begin{array}{l}\text { No } \\
\text { Yes }\end{array}$ \\
\hline $\begin{array}{l}\text { \# Observations } \\
\text { Adjusted } \mathrm{R}^{2}\end{array}$ & $\begin{array}{c}17,879 \\
0.686\end{array}$ & $\begin{array}{c}18,238 \\
0.754\end{array}$ & $\begin{array}{c}16,703 \\
0.719\end{array}$ & $\begin{array}{c}18,239 \\
0.518\end{array}$ \\
\hline
\end{tabular}




\section{Table 8 (continued): Analyses Addressing Alternative Explanations}

Panel B: Difference-in-difference analysis around Reg. NMS

\begin{tabular}{|c|c|}
\hline & $2007 \pm 2$ years \\
\hline$Q_{t-1}$ & $\begin{array}{l}0.732 * * * \\
(6.60)\end{array}$ \\
\hline$Q_{t-1} \times P O S T_{t-1}$ & $\begin{array}{l}0.009 \\
(0.08)\end{array}$ \\
\hline$Q_{t-1} \times P O S T_{t-1} \times L A R G E_{t-1}$ & $\begin{array}{l}0.542 * * * \\
(2.65)\end{array}$ \\
\hline$Q_{t-1} \times L A R G E_{t-1}$ & $\begin{array}{c}0.827 * * * \\
(4.40)\end{array}$ \\
\hline $\operatorname{POST}_{t-1} \times L A R G E_{t-1}$ & $\begin{array}{l}-0.568 \\
(-1.27)\end{array}$ \\
\hline$P O S T_{t-1}$ & $\begin{array}{c}-1.089 * * \\
(-2.07)\end{array}$ \\
\hline$L A R G E_{t-1}$ & $\begin{array}{c}-4.195 * * * \\
(-6.00)\end{array}$ \\
\hline$C F_{t}$ & $\begin{array}{l}0.035^{* * *} \\
(4.12)\end{array}$ \\
\hline$R E T U R N 3_{t}$ & $\begin{array}{c}-0.286^{* *} \\
(-2.50)\end{array}$ \\
\hline$I_{N V A S S E T S}{ }_{t-1}$ & $\begin{array}{l}0.079 * * * \\
(4.17)\end{array}$ \\
\hline Firm \& Year Fixed Effects & Yes \\
\hline $\begin{array}{l}\text { \# Observations } \\
\text { Adjusted R }{ }^{2}\end{array}$ & $\begin{array}{c}17,879 \\
0.745\end{array}$ \\
\hline
\end{tabular}




\section{Table 8 (continued): Analyses Addressing Alternative Explanations}

Panel C: Instrumental variable analysis using the number of trading venues

Stage 1: $F R A G_{t-1}=a_{0}+a_{1} \log (\# V E N U E S)_{t-1}+a_{2} Q_{t-1} \times \log (\# V E N U E S)_{t-1}+a_{3} Q_{t-1}$

$+a_{4} C_{t}+a_{5}$ RETURN3 $_{t}+a_{6}$ INVASSETS $_{t-1}+$ Firm Fixed Effects

+ Year Fixed Effects $+e_{t}$

$Q_{t-1} \times F R A G_{t-1}=a_{0}+a_{1} \log (\# V E N U E S)_{t-1}+a_{2} Q_{t-1} \times \log (\# V E N U E S)_{t-1}+a_{3} Q_{t-1}$

$+a_{4} C_{t}+a_{5}$ RETURN $_{t}+a_{6}$ INVASSETS $_{t-1}+$ Firm Fixed Effects

+ Year Fixed Effects $+e_{t}$

Stage 2: $C A P X_{t}=b_{0}+b_{1} Q_{t-1}+b_{2} Q_{t-1} \times$ Pred. FRAGt-1 $+b_{3}$ Pred. FRAGt-1 $+b_{4} C F_{t}$

$+b_{5}$ RETURN $_{t}+b_{6}$ INVASSETS $_{t-1}+$ Firm Fixed Effects

+ Year Fixed Effects $+e_{t}$

\begin{tabular}{|c|c|c|c|}
\hline & (1) & (2) & (3) \\
\hline Dep. Var. & $F R A G_{t-1}$ & $Q_{t-1} \times F R A G_{t-1}$ & $C A P X_{t}$ \\
\hline $\log (\# V E N U E S)_{t-1}$ & $\begin{array}{c}0.253 * * * \\
(13.55)\end{array}$ & $\begin{array}{c}1.344 * * * \\
(9.45)\end{array}$ & \\
\hline$Q_{t-1} \times \log (\# V E N U E S)_{t-1}$ & $\begin{array}{c}-0.003 * * * \\
(-12.93)\end{array}$ & $\begin{array}{c}0.040 * * * * \\
(7.55)\end{array}$ & \\
\hline$Q_{t-1}$ & $\begin{array}{c}0.007 * * * \\
(7.73)\end{array}$ & $\begin{array}{c}0.074 * * * * \\
(5.04)\end{array}$ & $\begin{array}{c}0.616 * * * \\
(6.13)\end{array}$ \\
\hline Pred. $\left(Q_{t-1} \times F R A G_{t-1}\right)$ & & & $\begin{array}{c}1.081^{* *} \\
(2.16)\end{array}$ \\
\hline Pred. FRAGt-1 & & & $\begin{array}{l}1.252 \\
(0.28)\end{array}$ \\
\hline$C F_{t}$ & $\begin{array}{c}0.000 * * * \\
(3.25)\end{array}$ & $\begin{array}{c}0.003 * * * \\
(7.84)\end{array}$ & $\begin{array}{c}0.029 * * * \\
(10.44)\end{array}$ \\
\hline RETURN3 $t_{t}$ & $\begin{array}{c}-0.004 * * * * \\
(-11.23)\end{array}$ & $\begin{array}{c}-0.020 * * * \\
(-7.62)\end{array}$ & $\begin{array}{c}-0.249 * * * \\
(-7.07)\end{array}$ \\
\hline INVASSETS $t-1$ & $\begin{array}{c}-0.000 * * * * \\
(-12.09)\end{array}$ & $\begin{array}{c}-0.003 * * * \\
(-10.61)\end{array}$ & $\begin{array}{c}0.018 * * * \\
(5.42)\end{array}$ \\
\hline Firm \& Year Fixed Effects & Yes & Yes & Yes \\
\hline $\begin{array}{l}\text { Kleibergen-Paap Wald F statistic } \\
\text { \# Observations }\end{array}$ & 109,020 & 109,020 & $\begin{array}{c}102.41 * * * \\
109,020\end{array}$ \\
\hline Adjusted $\mathrm{R}^{2}$ & 0.908 & 0.727 & 0.592 \\
\hline
\end{tabular}


Table 8, Panels A and B, present results from the estimation of Eqs. (10a) and (10b). Panel A displays the overall effect of Reg NMS on investment sensitivities, and Panel B displays results from a difference-indifferences analysis that uses small firms as a control group. In Panel A, Column 1, and Panel B, POST is an indicator that equals 1 for the two years after the implementation of Reg NMS in 2007. In Column 2 (3), POST is an indicator variable that equals 1 for the two years after 2005 (2009). In Column 4, POST is an indicator variable that equals 1 for the two quarters after the implementation of Reg NMS. Panel C presents results from a two-stage instrumental variable estimation of Eqs. (11a) through (11c). \#VENUES is the number of trading venues existing at the end of the firm's fiscal year. See Appendix 1 for all other variable descriptions. In Column 3 of Panel $\mathrm{C}, t$-statistics based on bootstrapped standard errors from 1,000 estimations are shown in parentheses. All other $t$-statistics are based on standard errors clustered by firm. $* * *, * *$, and $*$ denote significance at the $0.01,0.05$, and 0.10 levels, respectively. 